\title{
ابو القداء ودوره في تطوير الفكرة الاقليمية
}

الدكتور كمال عبدالله حسن

جامعة الانبار - كلية الآداب

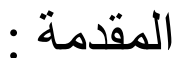

لقد حظيت فكرة الاقليم بأهمية كبيرة لدى الجغر افيين القدماء و المحدثين على حد سواء ـ اذ طر أت عليها تطورات عدة ، وحملت في طياتها تصورات مخنلفة ـ فمنذ عهد الحضار ات القديمة ، مروراً بالحضارة الاسلامية ، و عصر بروز الجغر افية الحديثة ، و عهد الاباء الروحيين للجغر افية امثال همبولدت و ريتر ، ومن تبعهم من الجغر افيين الى يومنا هذا ـ و الاقليم يمثل لبنة اسـاسية وحجر الزاوية في علم الجغر افية ـ الا ان هذه الاهمية لم تأت دن فر اغ ، و هذا التطور لم يبنى من قبل نفسه ، بل ساهم بـه علماء افذاذ ، واساتذة عظام حتى وصل الينا كما هو اليوم ـ وبحثنا هذا ينصب على در اسة تطور فكرة الاقليم وبيان دور احد الجغرافيين المسلمين في هذا التطور الا وهو الجغرافي

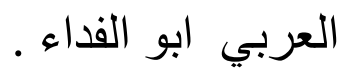

مشكلة البحث : يمكن تحديد المشكلة بالتساؤل الاتي : ما مدى مساهمة ابي الفداء في تطوير الفكرة الاقليمية .

فرضية البحث : ان مساهمة ابي الفداء في تطوير الفكرة الاقليمية لا تقل اهميةً عن اكتشاف فكرة الاقليم وبالتالي فأن لأبي الفداء دور كبير في تطوير تطوير فكرة الاقليم وتحديده وايصالها لنا بشكلها الحالي.

$$
\text { حدود البحث : يمكن تحديد البحث بالحدود الاتية :- }
$$

الحدود المكانية : يتحدد البحث بحدود العالم الاسلامي واقاليمه ( مملكة

$$
\text { الاسلام ). خريطة (1) }
$$


الحدود الزمانية : تتمثل الحدود الزمانية بالقرن السابع الهجري - الثالث

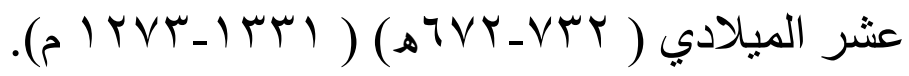

منهجية البحث : اعتمد البحث المنهج الاستقرائي منهجاً فكرياً له ، كما اعتمد المنهج الاقليمي ليكون منهجاً كتابياً ، و الذي كان لموضو الاعي مع البحث دور كبير

$$
\text { في تطويره }
$$

هدف البحث : يهدف البحث الى بيان دور احد رواد الفكر الجغر افي في تطوير الفكرة

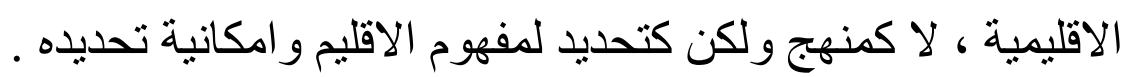

\section{اولاً :التعريف بابي القداء :}

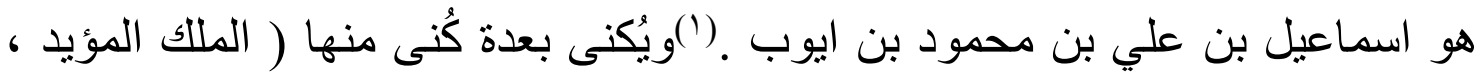

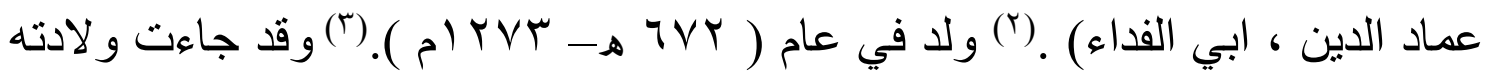

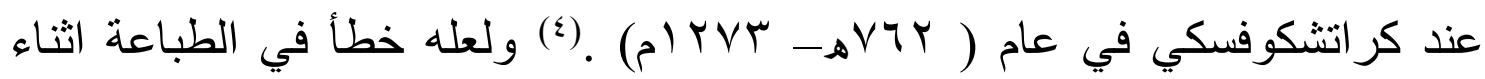
الترجمة ، اذ ان العام الميلادي هو نفسه و الخطأ هو في العام الهجري فقط ـ .يرتبط نسبه بالمظفر بن شاهنشاه ابن اخ صلاح الدين الايوبي .(0) ولعل نسبه هذا ، وحكم عائلته لمدينة حما صنعت منه قائداً فذاً فاشترك في في عدد من المعارك ، منذ بداية شبابه

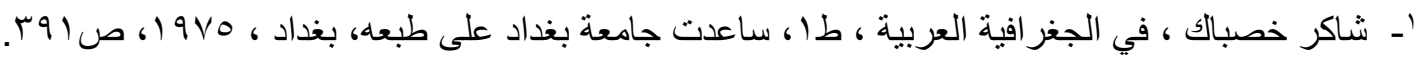
r - عبدالرحمن حميدة ، اعلام الجغرافيين العرب ومقتطفات من اثارهم ، طع، دار الفكر ، سوريا ، 1990 ،

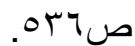

rـ شاكر خصباك ، المصدر السابق ، ص اqج. ؛ـ اغناطيوس يوليانوفتش كر اتشكوفسكي ، تاريخ الادب الجغر افي العربي ، ترجمة صلاح الدين عثمان هانشم،

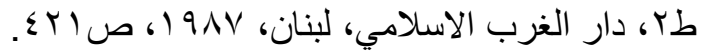

•ـ شاكر خصباك ، كتابات مضيئة في التراث الجغرافي العربي ، طا، مطبعة دار السلام ، بغداد ، rr. r. I (9V9 


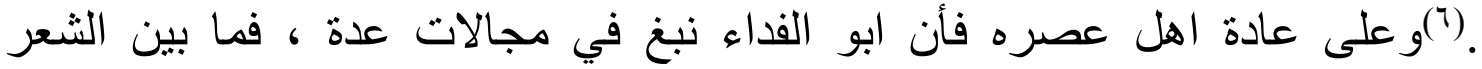

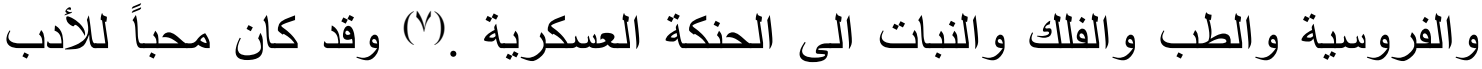

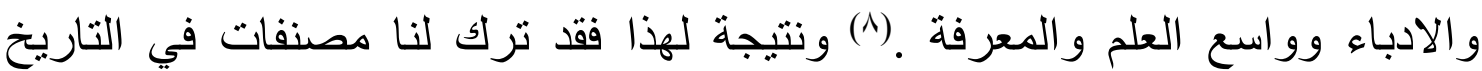

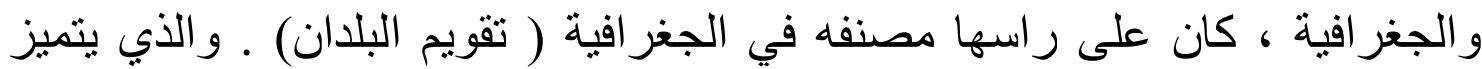

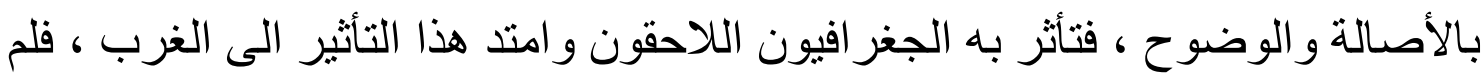

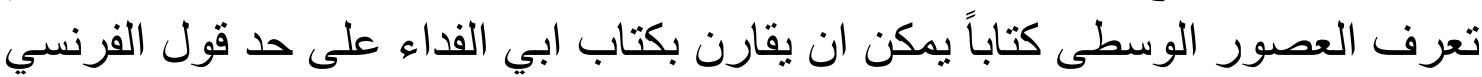

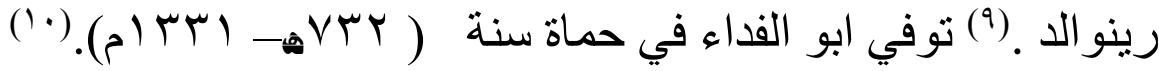
ثانياً:الحاجة الى الاقليم :

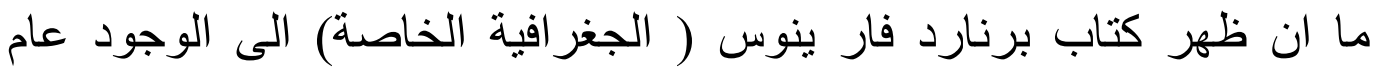

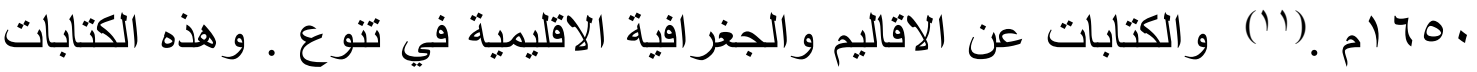

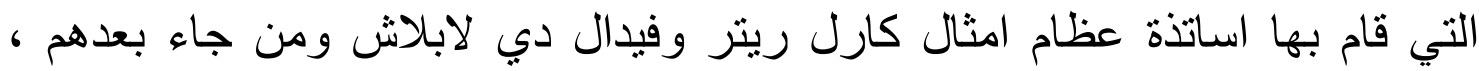

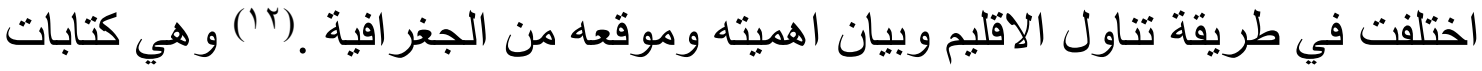
و ضنعرث حجر

جـ علي عبداله الدفاع ، رواد علم الجغر افية في الحضارة العربية الاسلامية ، طץ، مكتبة التوبة ، المملكة العربية

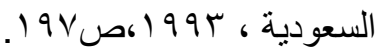

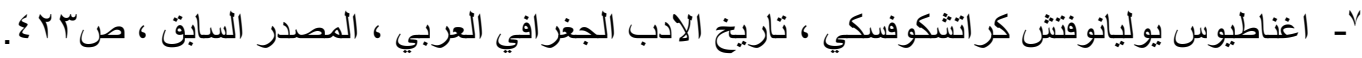
^ - ـ ابراهيم احمد سعيد وممدوح شعبان دبس ، تطور الفكر الجغرافي ، منشورات جامعة دمشق ،

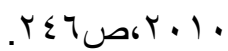
9ـ خالد حربي ، الجغر افيا في الحضارة الاسلامية الدور والتاريخ ، مجلة الر افد ، دائرة الثقافة والاعلام ، الثارقة

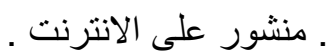

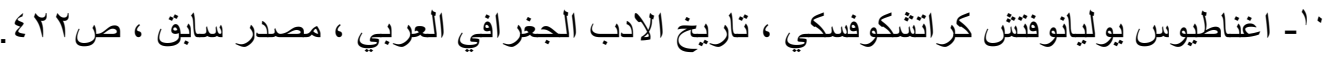
R.E. Dickinson, Regional Concept, The Anglo-America Leaders, Routledge and -' KeganPaul, London , 1976,P.151.

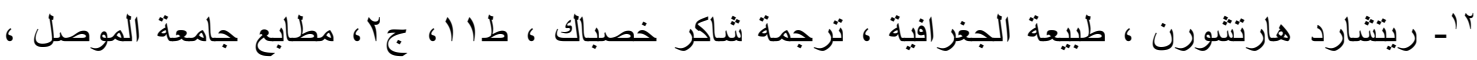
(19V7 
خريطة (1)

مملكة الاسلام في القرن الرابع الهجري

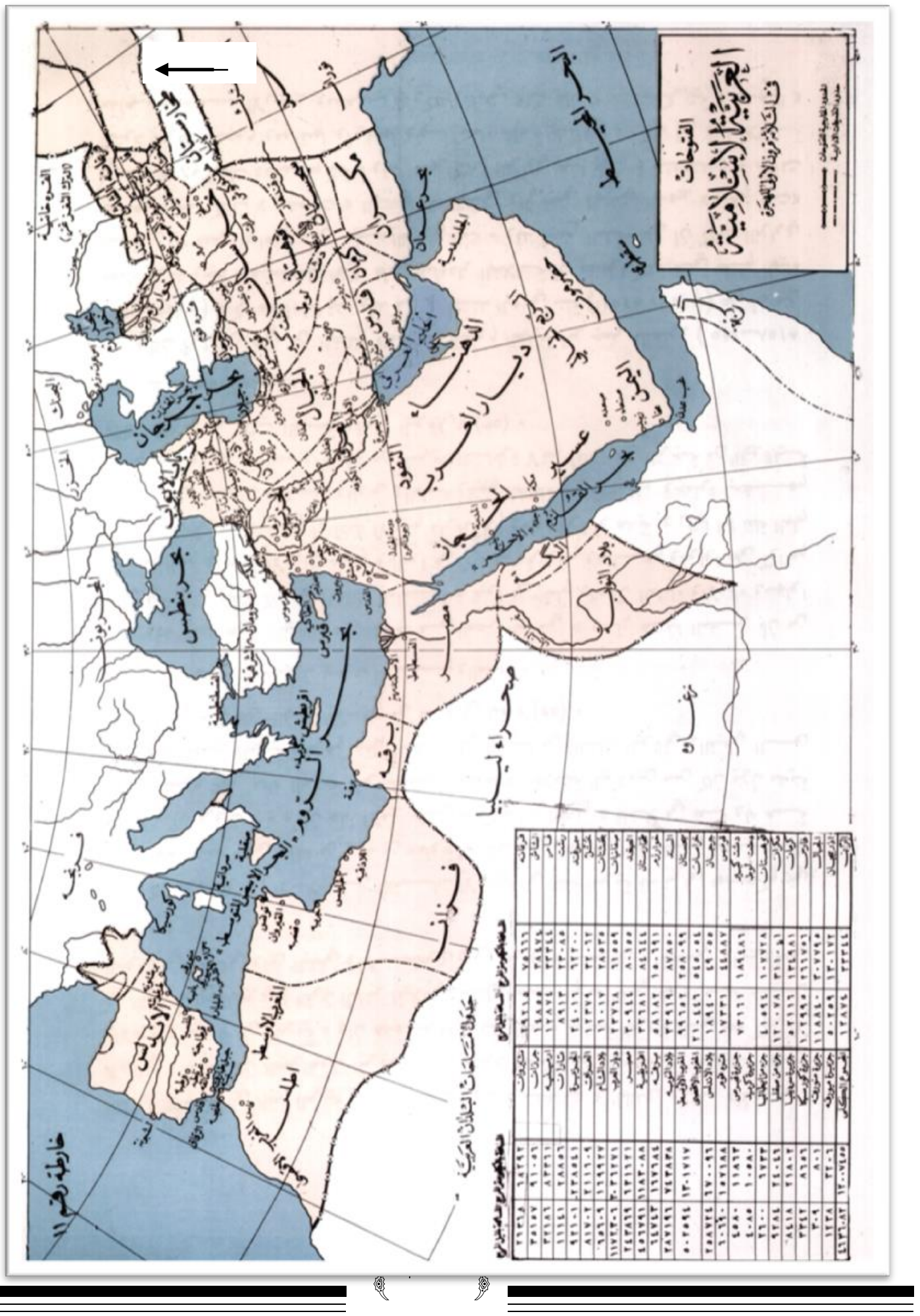


المصدر : احمد سوسة، الثريف الادريسي في الجغرافية العربية ، جا، نقابة المهندين العراقيين ، مكتبة صبري

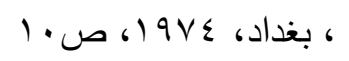

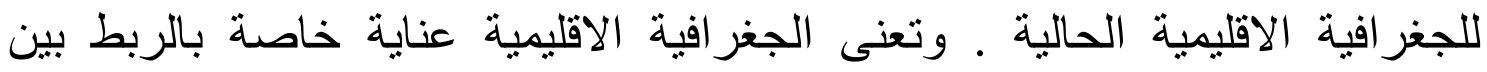
الظاهر ات الجغر افية المختلفة ( طبيعية و احيائية و اجتماعية) لإبراز العلاقات المركبة

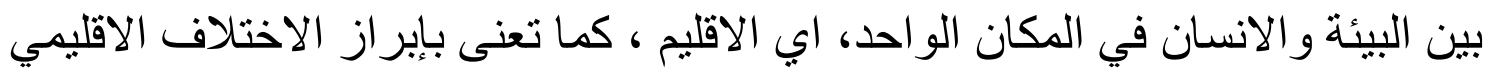
في الوحدة المكانية موضع الدراسة .(rا") ويمثل الاقليم (اللبنة الاساسية في الجغرافية لإنية الاقليمية) الحيز الذي تدور فيه و عليه فلسفة المكان بأبعادها المختلفة . (ء) وبما انه اللبنة الاساسية في الجغر افية الاقليمية ، فقد تعددت تعريفات الاقليم بحسب الحاجة اليه ، وبحسب التخصص الذي تناوله ـ ومن هنا يرى فريمان ان لكلمة (اقليم ) العثر ات من التعاريف و المعاني التي تمتد الى ما وراء الجغر افية .(10) الا ان الاقليم بأبسط تعريفاته هو جزء من سطح الارض يتميز بثكل ما عن المناطق المحيطة به ـ ("ال) و الحاجة لهذا الاقليم جاءت من امرين اساسيين ، الاول : ان الاقليم يمثل العنصر الاساس الذي مئي يتكون منه المركب ، اي بدون الاقليم لم يكن للجغرافية الاقليمية ان ترى النور ، ولم يكن بالإمكان تعدد المناهج البحثية ما بين اقليمية وموضوعية . والثاني : تعدد العلوم و التخصصات التي تناولت الاقليم بحسب حاجتها ـ وبالتالي فان هذا الاقليم نُظر اليه من وجهتين ، الاولى ، موضوعية (Opjective) ترى في الاقليم غاية بحد ذاتها ، صيخة حقيقية ، كائن عضوي يمكن تشخيصه ورسمه ، و الثانية ، لا موضو عية

ז' ـ محمد محمد سطيحة ، الجغر افية الاقليمية ـ دراسة لمناطق العالم الكبرى، طا ، دار النهضة العربية للطباعة

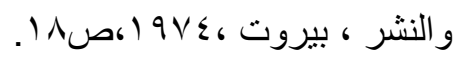

؛ ــ خالص حسني الاشعب ، اقليم المدينة بين التخطيط الاقليمي والتنمية الثاملة ، مطابع التعليم العالي ، بيت

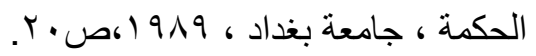

هـ تي ـ و ـ فريمان ، الجغر افية في مئة عام ، ترجمة عبدالعزيز طريح شرف ، دار الثؤون الثقافية ، بغداد ،

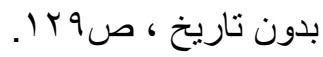

David Grigg, Regional, Models and Classes, Models in Geography, Second - ${ }^{14}$ Published, London, 1987 , P. 463. 


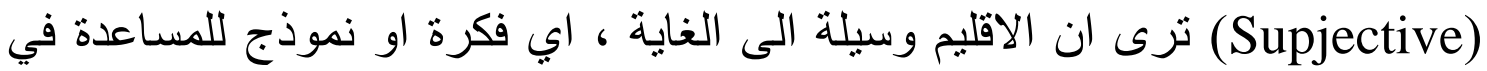

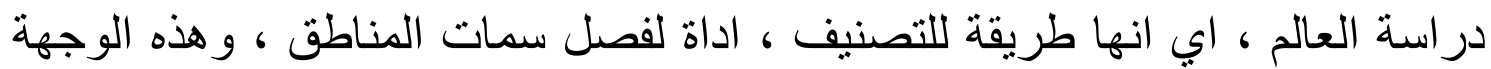

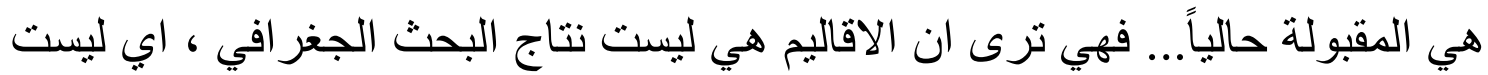

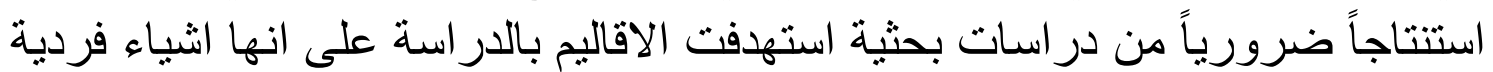

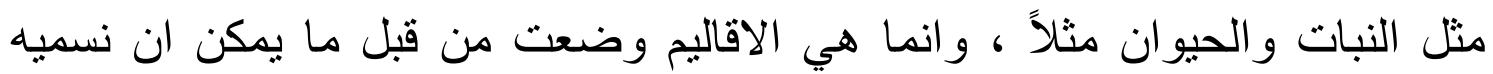

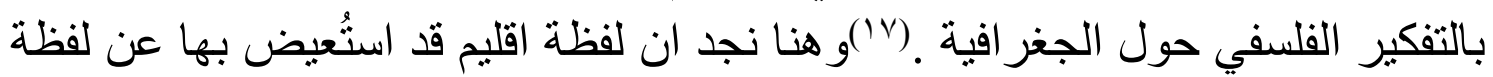

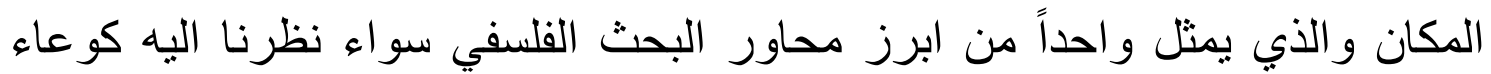

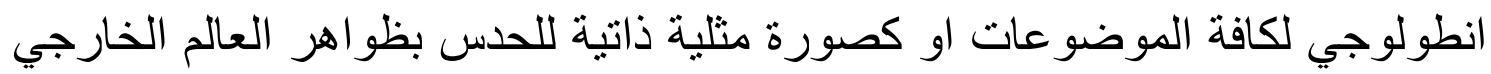

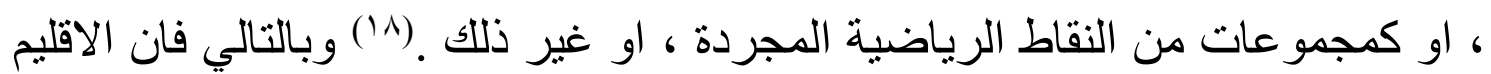

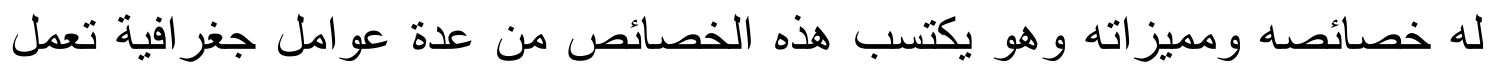

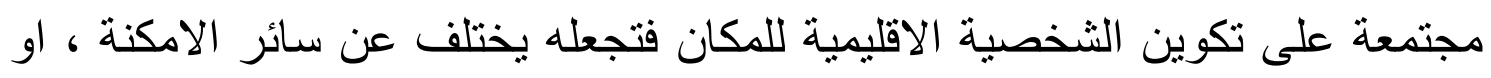
على الاقل تكون له صفات تميزه عن غيره من الاماكن ، ومن ثم كانت الاته الاقليمية

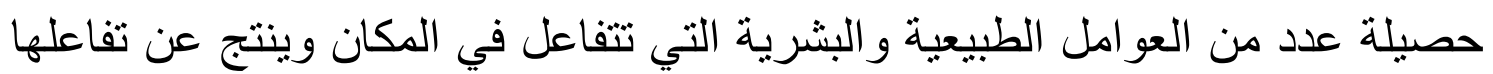

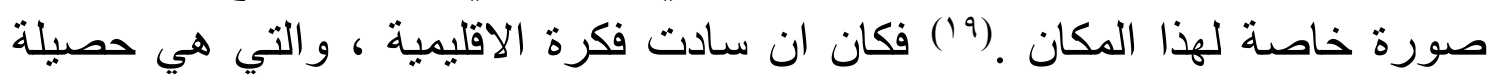

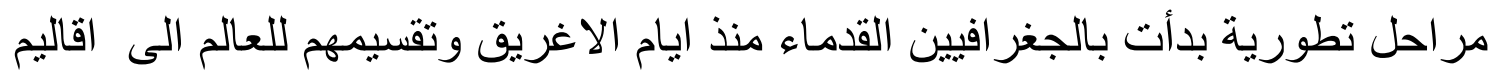

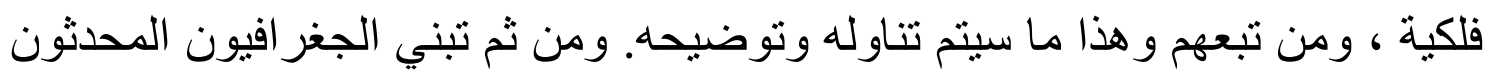

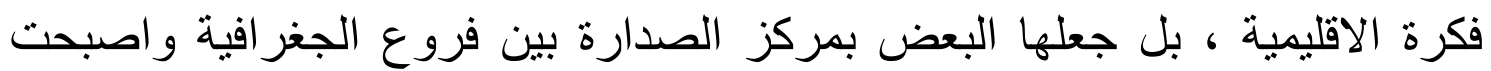

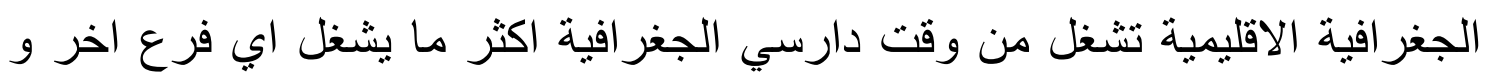

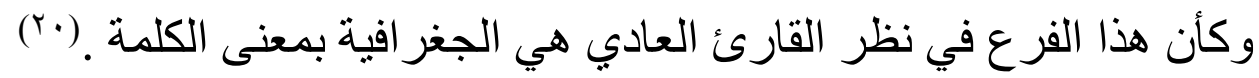

Vا'- جون كلاسون ، مدخل الى التخطيط الاقليمي-المفاهيم النظرية والتطبيق ، ترجمة اميل جميل شمعان ، طب ،

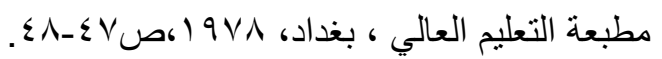

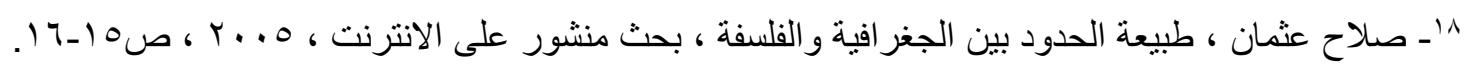

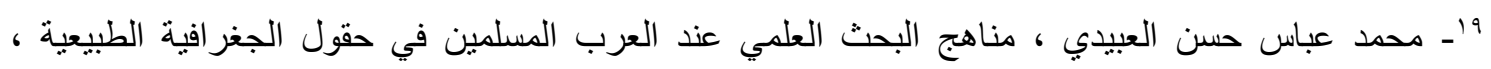

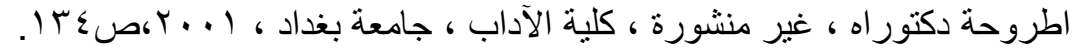




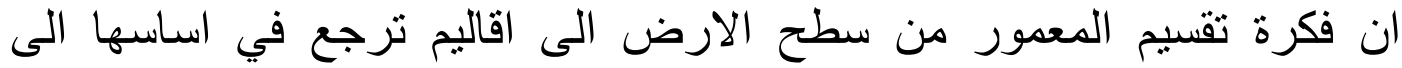

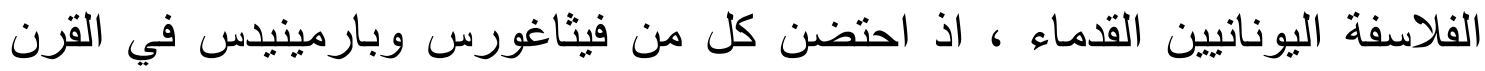

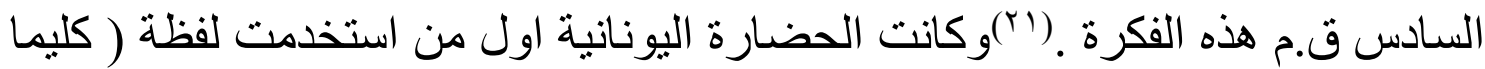
(Klima

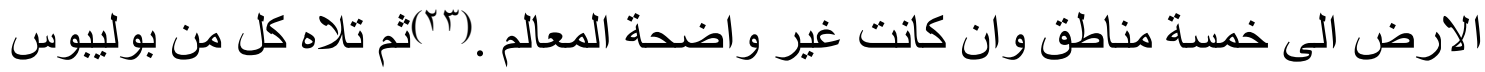

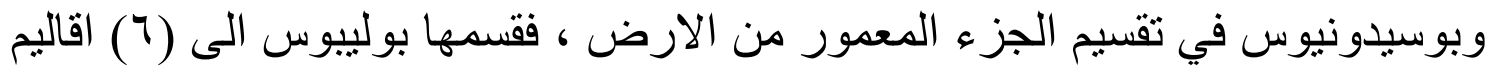

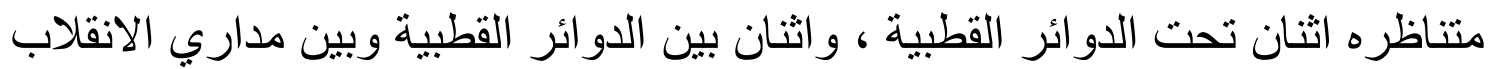

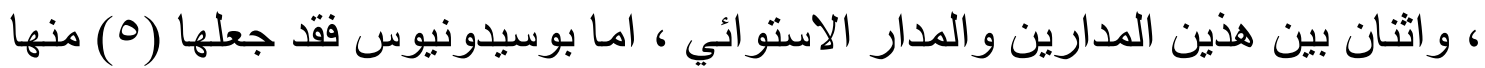
اثنان تحت القطبين ، و اثنان يمتدان الى ما بعدهما حتى حدود سكنى الناس عند مدان مدارين

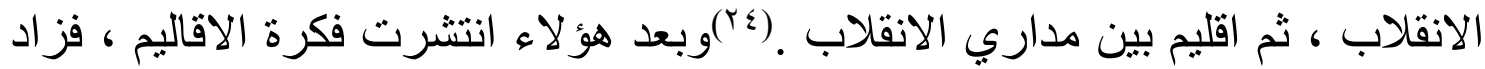

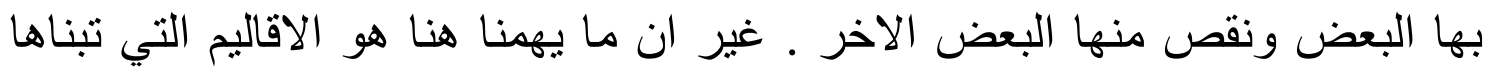

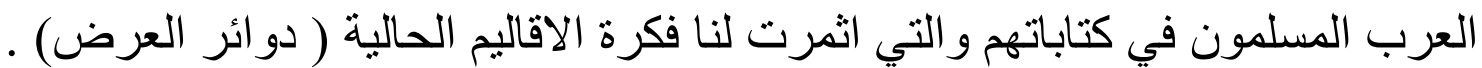

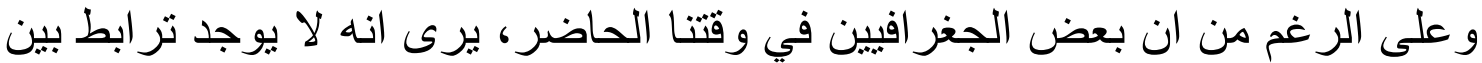
الافكار التي سيتم تناولها ( فكرة الكثورات وفكرة الاقاليم الفلكية وفكرة الاقاليم

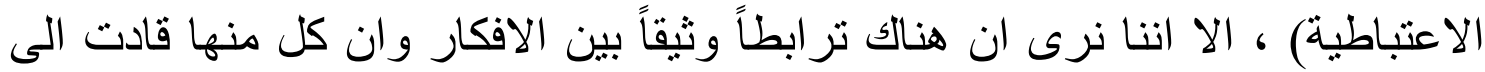

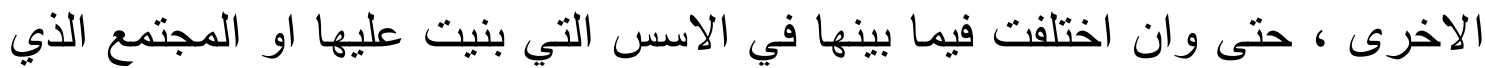

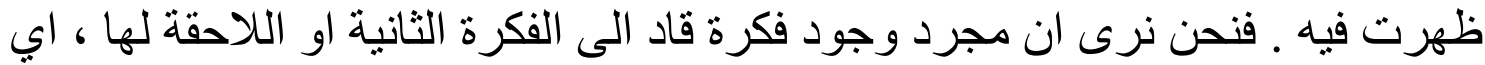
انها كانت الجذوة التي اوقدت منها النار ـ كما ان كل الافكار اتخذت من كلمة اقليم

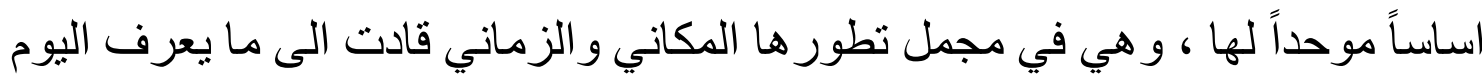

$$
\text { اrـ احمد سوسة ، الثريف الادربسي في الجغر افية العربية ، مصدر سابق ، صوبr. }
$$

rr ـ نداء نجم الدين احمد العبيدي ، دور الفكر الجغر افي العربي الاسلامي في تحديد مفهوم الجغرافية الاقليمية ،

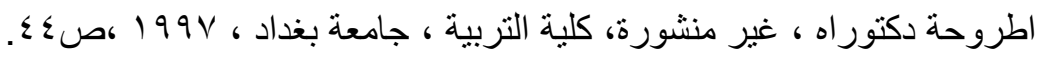

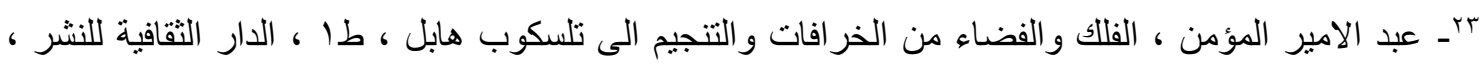

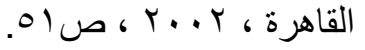

צ' احمد سوسة ، الثريف الادريسي في الجغر افية العربية ، المصدر السابق ، ص.بr؟. 
بعلم الاقليم و الجغر افية الاقليمية ـ كما انها ارست قو اعد تحديد اي منطقة او بقعة من العالم بحدود ، سو اء اكانت فلكية او جغر افية او الاثتين معاً.

\section{رابعاً :الفكرة الاولى ( فكرة الكثورات).}

الكِثَرَ و الكُشخَر كلمة فارسية بمعنى القسم ، الا ان العرب استبدلتها بلفظ

سرياني و هو الاقليم .(10) وقد نبنى العرب هذا التقيم الفارسي للعالم المعدور قبل ان

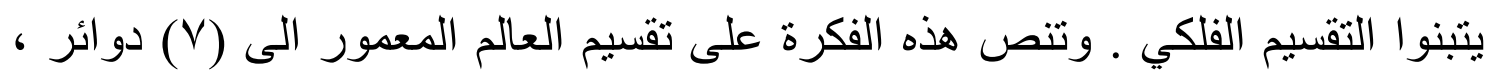
بعد ان قسمو ا اير انشهر الى ست دوائر ـ وقد أختلف فيما اذا كانت هذه السبعة اقاليم متناظرة ( اي سبعة شمال خط الاستو اء وسبعة جنوبه) ـ و هذا ما قال به هُرمَس الحكيم

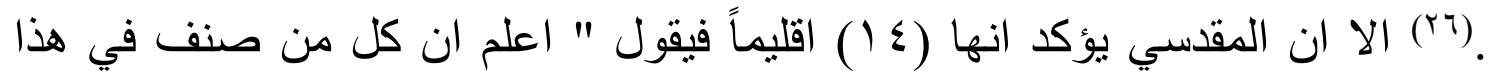

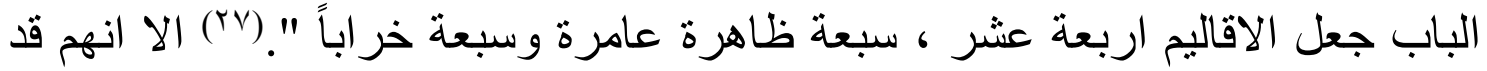
استقروا على انها سبعة اقاليم تمثل الجزء المعدور من الارض وهو يقع شمال خط الاستو اء على اعتبار ان السبعة الباقية خراب كما يقول المقدسي اذ انها غير مسكونة لثدة الحر او البرد ـ. وهذه الاقاليم السبعة او الكثور ات عبارة عن سبع دوائر متماسة ، تحيط ست منها بواحدة مركزية ، فوضعت اير انشهر او بابل في المنتصف وتمثل

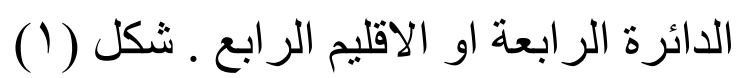
ومما يلاحظ على هذه الفكرة انها استخدمت الجهات الاصلية ، ولو انها رُسمت مقلوبة على عادة العرب بوضع الجنوب في الثمال . كما انها رُبطت بالبروج و الطو الع ومكان تو اجد القمر بحسب البرج او فللك البرج الذي يوجد فيه ، ونجد هذا مذيلاً في شر حُ كل اقليم

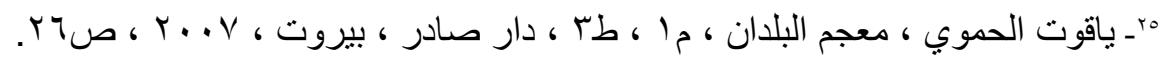
Yr_ المصدر نفسه ، ص OY. YYY محمد بن احمد المقسي ، احسن التقاسيم في معرفة الاقاليم ، ليدن المحروسة ، 7 ـ 19 ، ص10. 
و هذه الاقاليم هي (r^)

\begin{tabular}{|c|c|c|c|}
\hline التفاصيل & الاسم & الاقليم & ت \\
\hline وزابلستان وطخارستان الوسطمل العراق وفارس والجبل وخراسان وسجستان & بابل & الاقليم الرابع & $T$ \\
\hline و وهد والى الجنوب من الاقليم الرابع مباشرة ويشمل الحجاز والحبشة & الحجاز & الاقليم الثاني & $r$ \\
\hline وخرخير وكيماك والروس والثمال من الصقالبة مباشرة ويثمل الخزر و الترك والغز & و إنأجوج & الاقليم السادس & 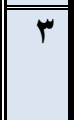 \\
\hline والمغوب الى الغروان من الأنين في البراري والبرابع ويشمل الثشام ومصر الى اقصى & مصر & |الاقليم الثالث & $\varepsilon$ \\
\hline وفرنجه وبر الغرب الثمالي من الاقليم الرابع ويشمل الروم والاندلس & الروم & الاقليم الخامس & 0 \\
\hline 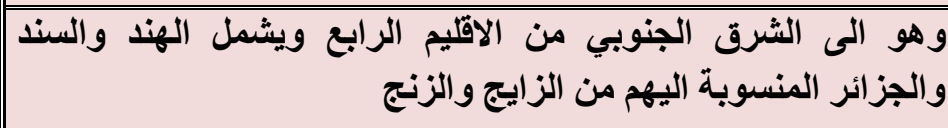 & الهند & الاقليم الاول & 7 \\
\hline و ها وراء الى الثهرق والاتراك الاقليم الرابع ويثمل الصين والتبت والختن وبلاد & الصين & الاقليم السابع & $\mathrm{v}$ \\
\hline
\end{tabular}


شكل (1) 1 (1)

الكثور ات كما وردت عند ياقوت الحموي

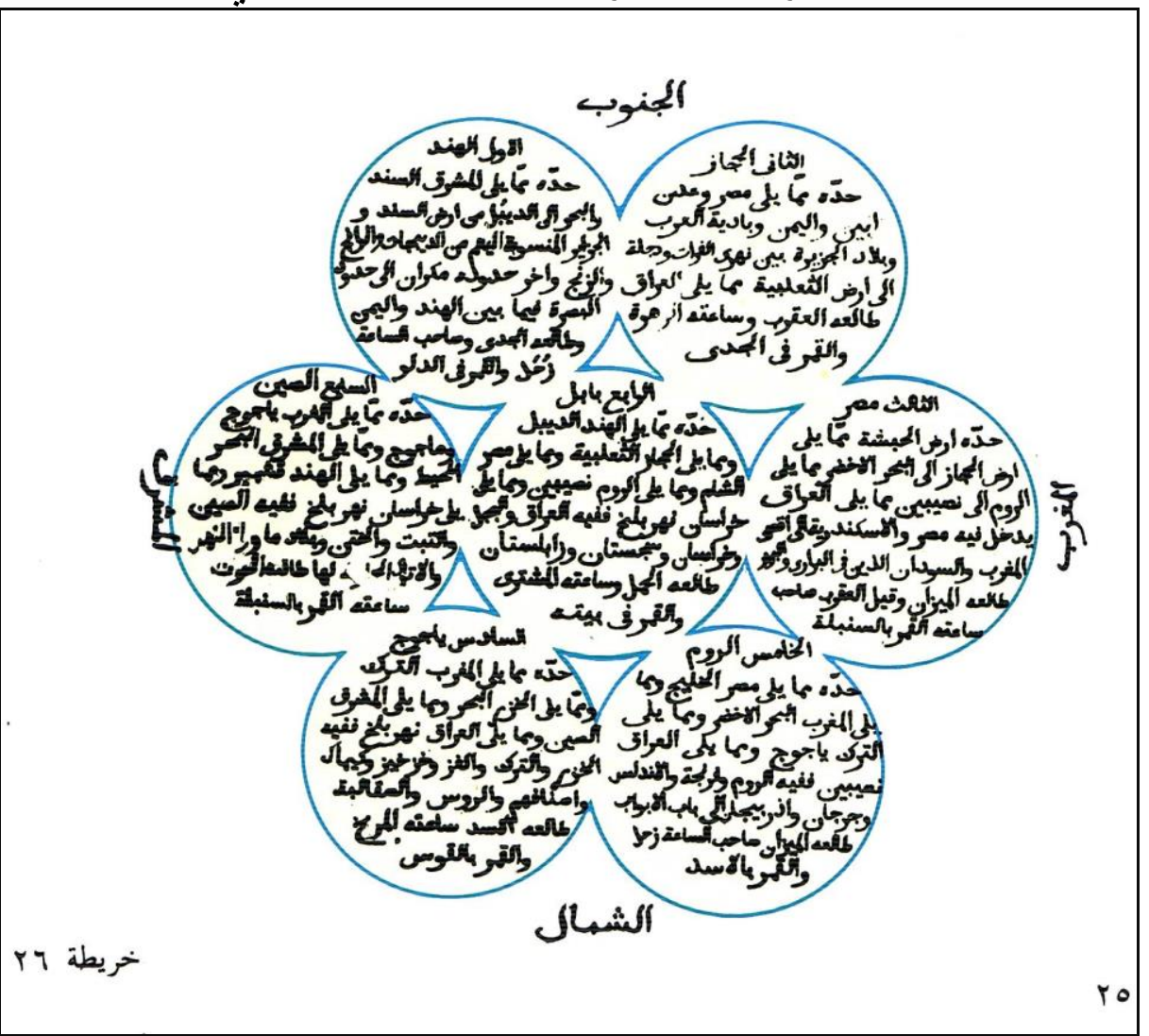

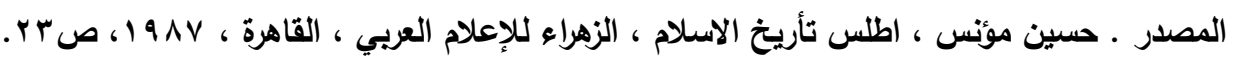

خامساً:(الفكرة الثانية ( الاقاليم القلكية) .

اثرنا في الفقرة السابقة الى ان فكرة الاقاليم الفلكية كانت بدايتها على يد اليونانيين

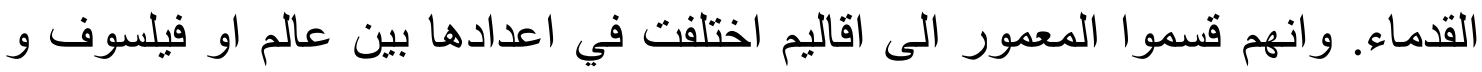

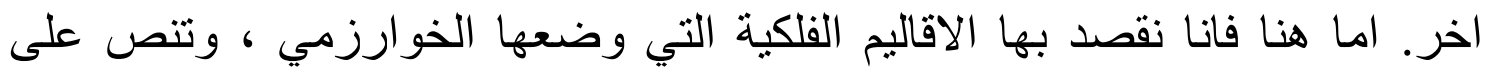

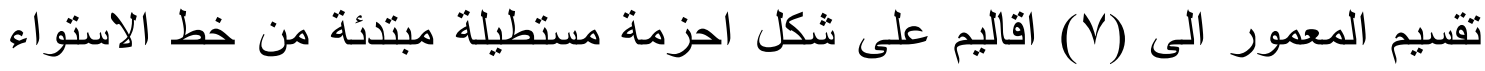

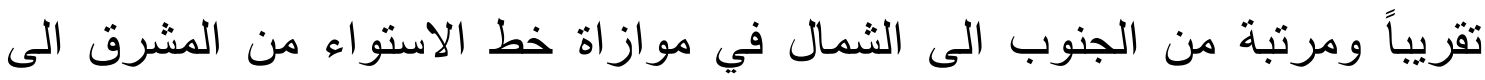

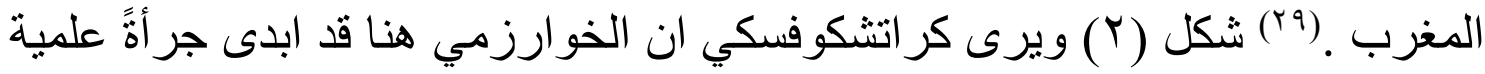


واضحة في تقسيمه الجديد للأقاليم ، وهي جرأة اظهرت اصالة وابتكار في خارطاته.(·r) وقد اعتمد الخوارزمي

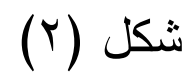

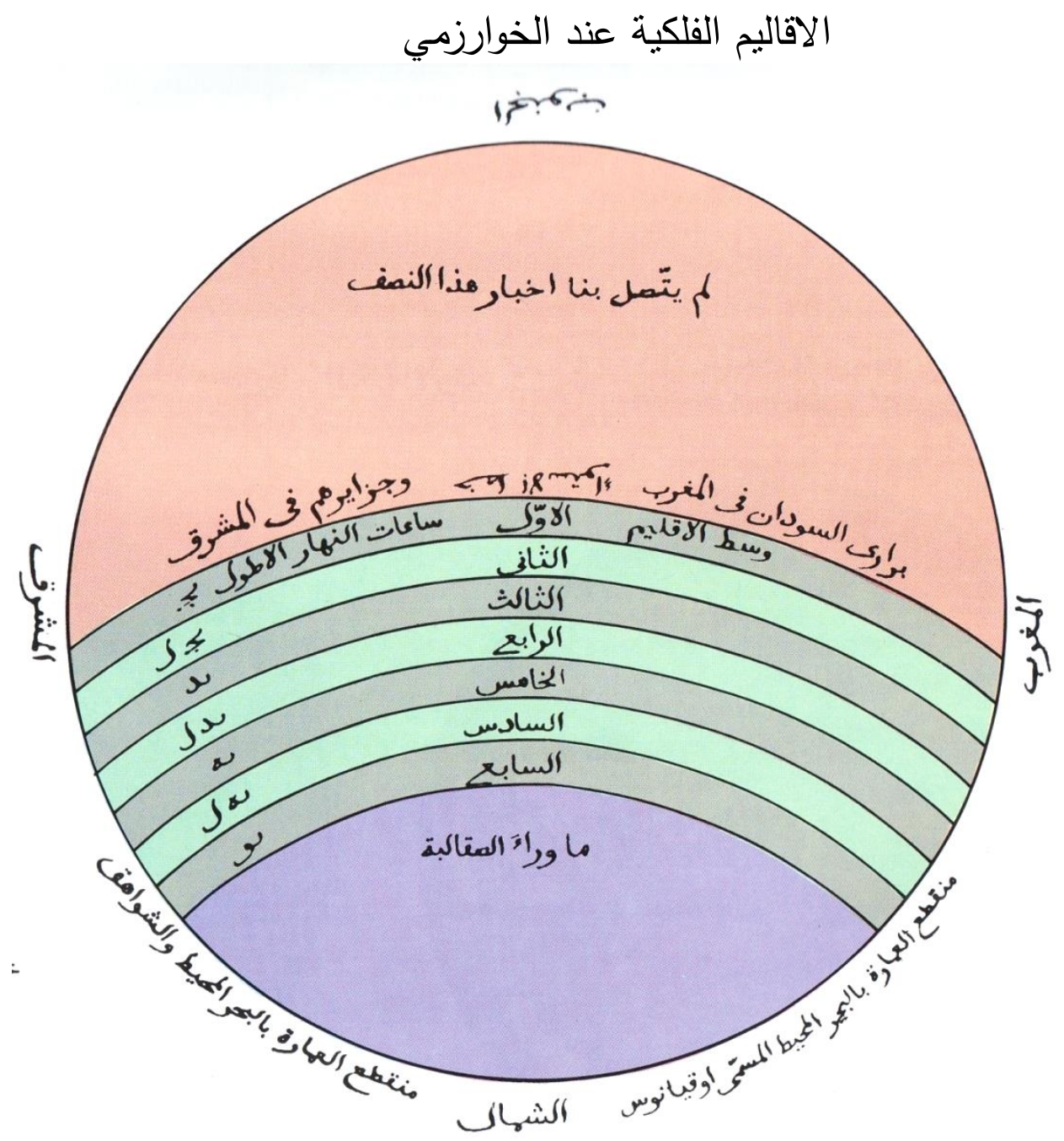

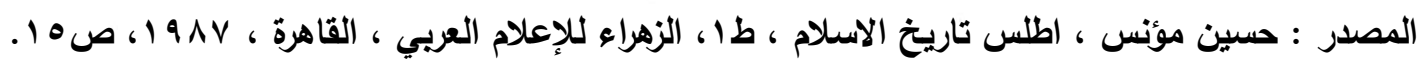

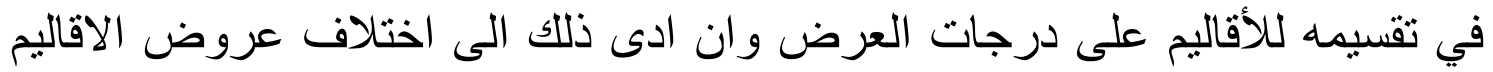
بسبب عدم الاتفاق على درجات العرض الفاصلة بين الاقليم و الذي يليه ـ (اب) اي اعتماد

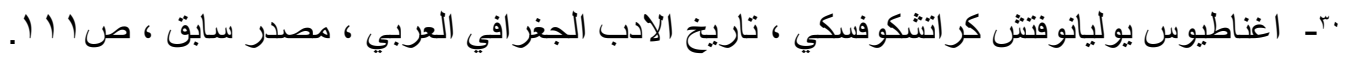


طول النهار صيفاً ، فيكون الفرق بين اقليم واخر نصف ساعة ، وكلما تقدمنا نحو

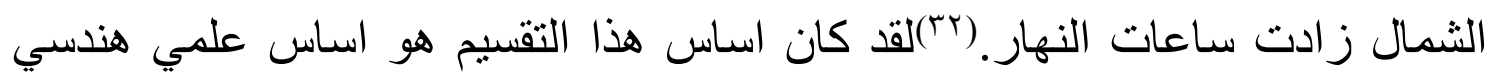

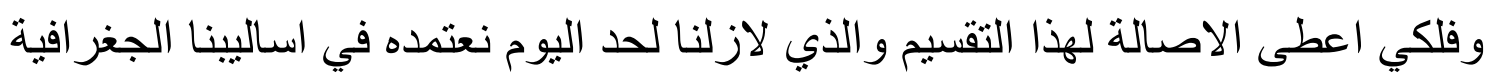

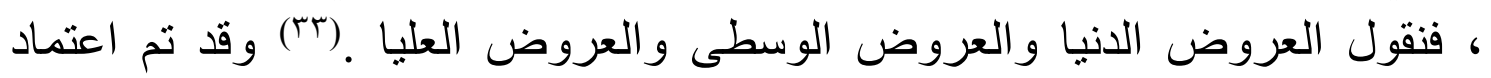

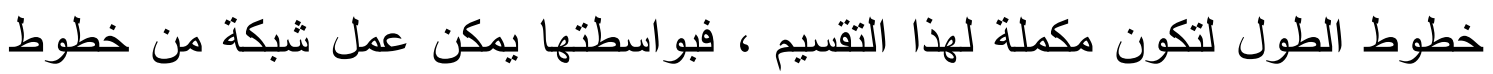

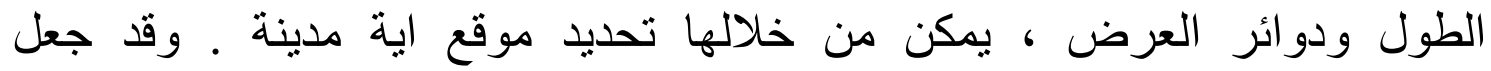

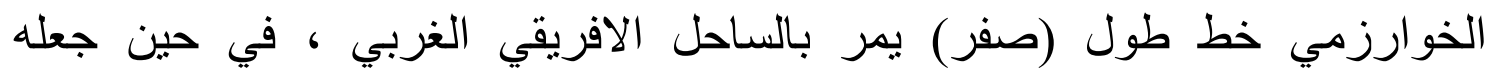

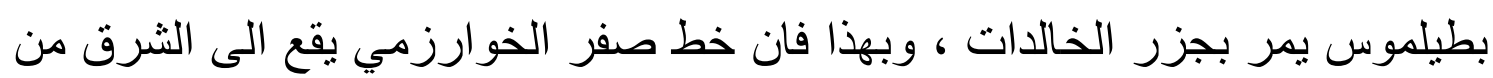

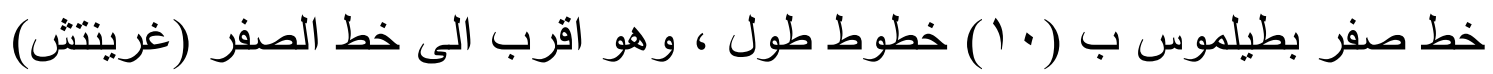
الحالي .

سادساً:(الفكرة الثالثة ( فكرة الاقاليم الاعتباطية)

سادت فكرة الخوارزمي او الاقاليم الفلكية ردحاً من الزمن ، فثملت القرن

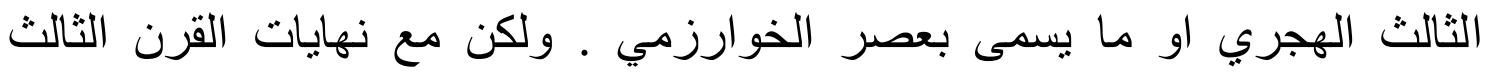

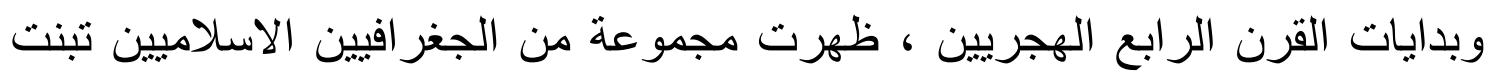

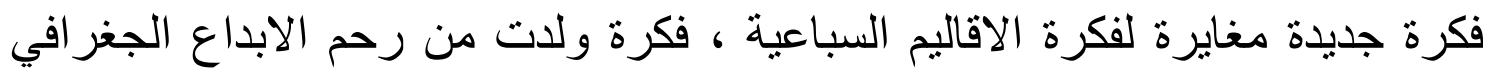

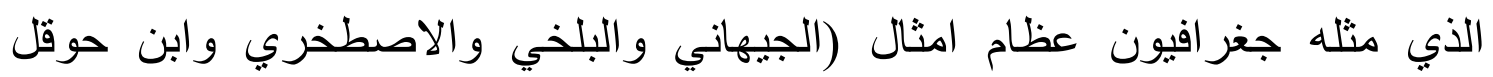

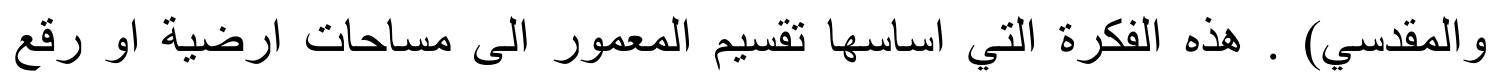

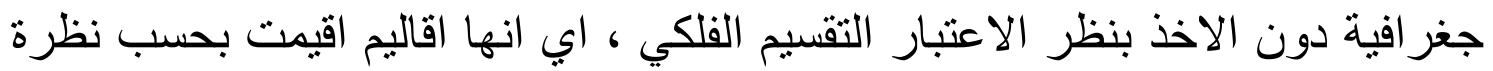

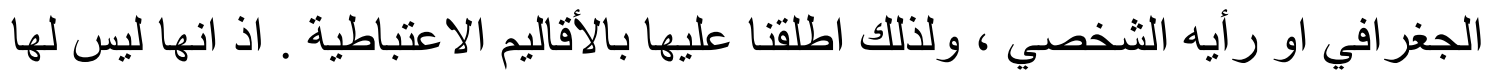

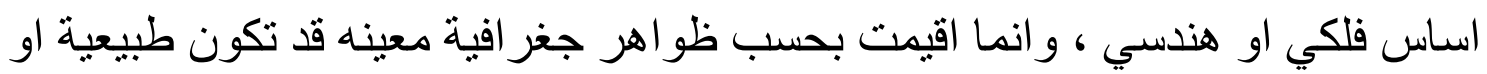

آــ نداء نجم الدين احمد العبيدي ، دور الفكر الجغر افي العربي الاسلامي في تحديد مفهوم الجغر افية الاقليمية ،

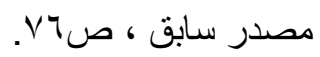

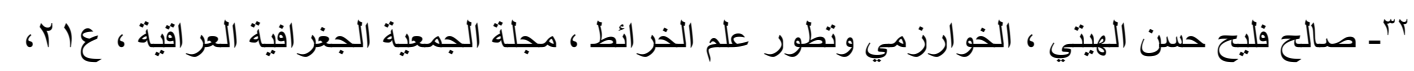

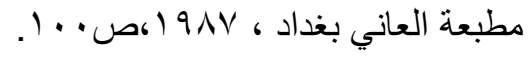
rr المصدر نفسه ، صr • (1. 
بشرية ، اقاليم حسب المتعارف عليها بين الناس او بحسب الانتاج او بحسب اللغة او الدين ، مع الاخذ بنظر الاعتبار ان الهدف من هذا التقيم كان التعرف على مملكة

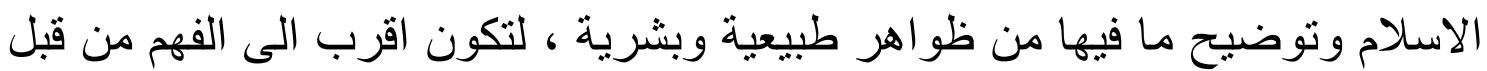
الكل خاص كان او عام .(عَ) و هذا ما يؤكده المقدسي بقوله " اعلم ان مملكة الاسلام حرسها الله تعالى ليست بمستوية فيمكن ان توصف بتربيع او طول او عرض وانما هي منشعبة يعرف ذلك من تأمل مطلع الثمس ومغربها ودوّخ البلدان و عرف المدالك الك و مسح الاقاليم بالفر اسخ وسنجتهد في تقريب الوصف وتصويره لذوي العقول والافهام ان شاء الله تعالى ".(ro) وقد اختلفت هذه الاقاليم في اعدادها بين جغر افي واخر ـ فقد

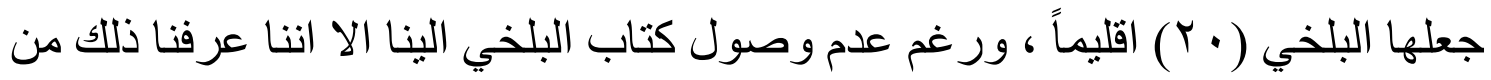
اشارة المقدسي بقوله " و اما ابو زيد البلخي فانه قصد بكتابه الامثلة وصورة الارض وض

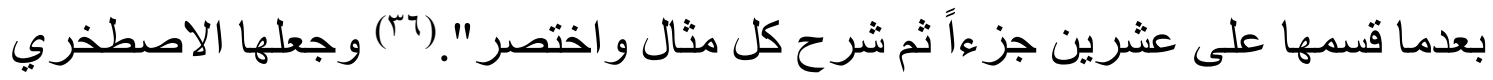

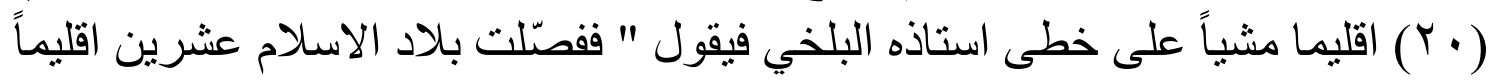
و ابتدأت بديار العرب ".(rV) اما ابن حوقل فقد جعلها (YY) اقليماً . في حين جعلها المقدسي (ع ا) اقليماً فيقول " وقد قسمناها اربعة عشر اقليماً وافردنا اقاليم العجم عن اقاليم العرب ".(^"). ومع اتخاذ الجغر افيون البلدانيين لهذا التقسيم ، الا انهم لم يكونوا جاهلين بالتقسيم السباعي ، فقد كانوا على دراية تامة به ، الا انهم ار ادوا لأنفسهم طريقاً جديداً يكون اكثر وضوحاً وتفصيلاً ، يمكن من خلاله توضيح ماهية مملكة الاسلام وما تحويه ـ و هنا يشير ابن حوقل الى ذلك بقوله " ولم اقصد الاقاليم السبعة التي عليها قسمة الارض لان الصورة الهندية التي بالقو اذيان وان كانت صحيحة فكثيرة التخليط وقد جعلت لكل قطعة افردتها تصويراً وشكلًا يحكي موضع ذلك الاقليم

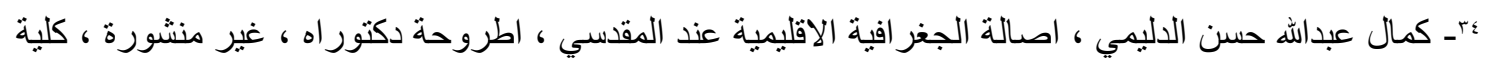

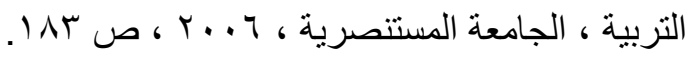
•r ـ محمد بن احمد المقدسي ، احسن التقاسيم في معرفة الاقاليم ، مصدر سابق ، صبآ.

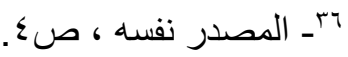

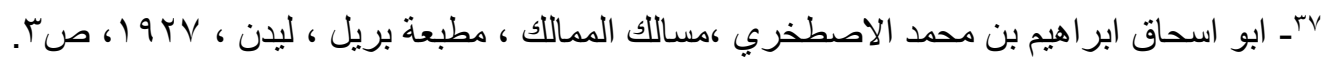

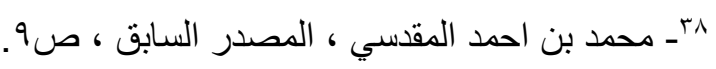


".("ج)ويشير الى ذلك الاصطخري ايضاً بقوله " ولم اقصد الاقاليم السبعة التي عليها

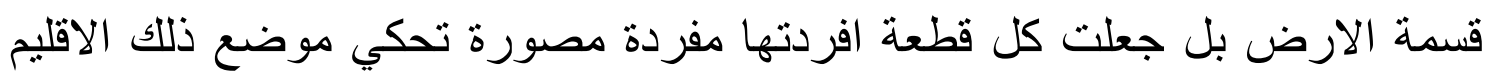

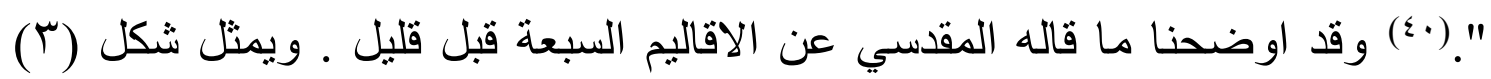

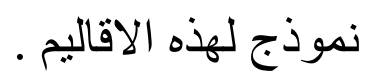

\section{سابعاً : الفكرة الرابعة ( فكرة الادريسي) :}

مع بلوغ الجغر افية العربية قمة نضوجها وازدهار ها في القرن الرابع الهجري على يد العزي

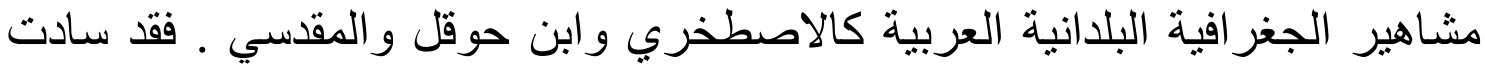

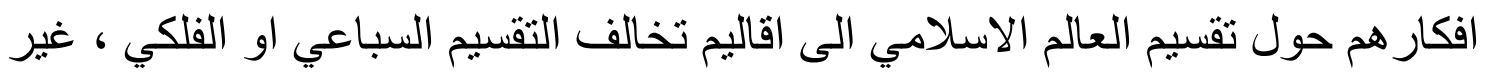

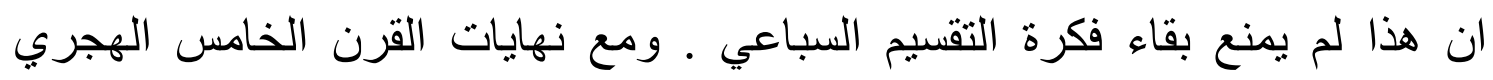

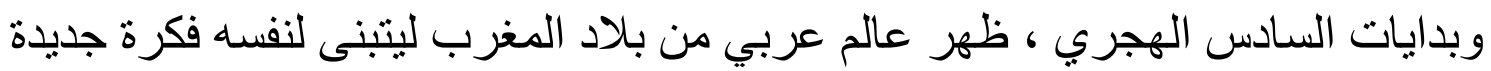

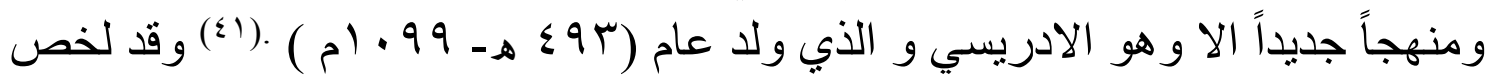
الادريسي

\section{الاقاليم \\ الاعتباطية عند}

الاقاليم الاعتباطية عند ابن حوقل

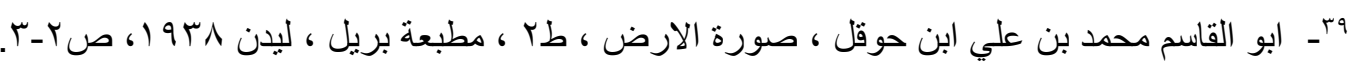

•ـ ابو اسحاق ابر اهيم بن محمد الاصطخري ، المصدر السابق ، ص ؟.

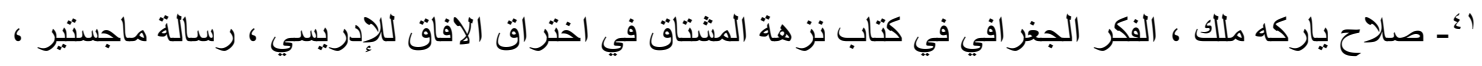

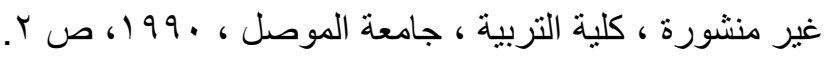




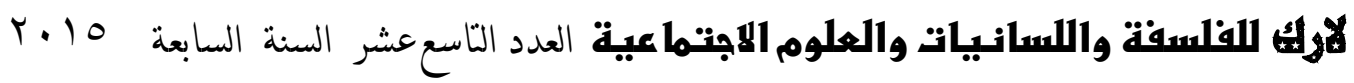

(r) شكل (1)

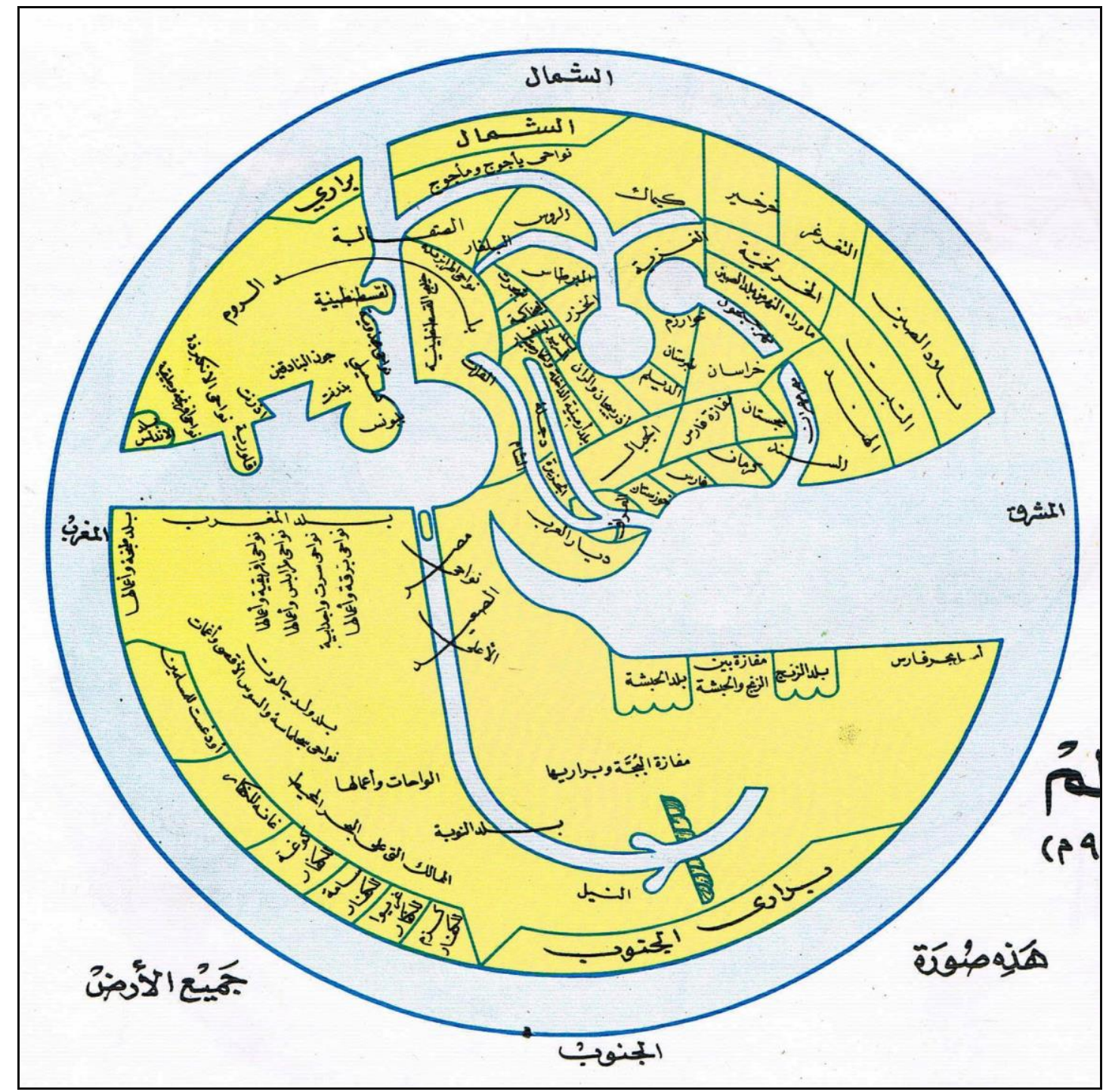

المصدر : حسين مؤنس ، اطلس تاريخ الاسلام ، طا، الزهراء للإعلام العربي ، القاهرة ، 9Av 19 ص10. 
منهجه هذا في كتابه نزهة المشتاق في اختراق الافاق ، و الذي انتهى من تأليفه سنة

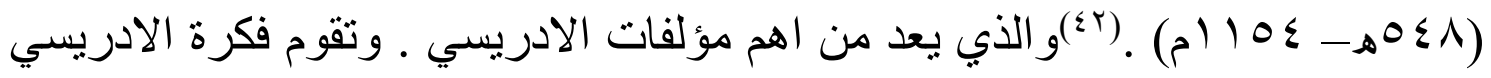

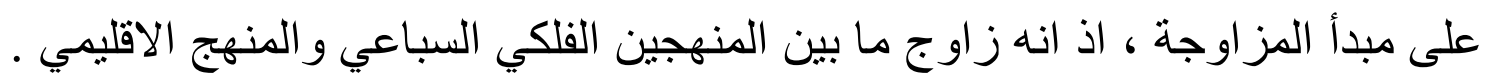

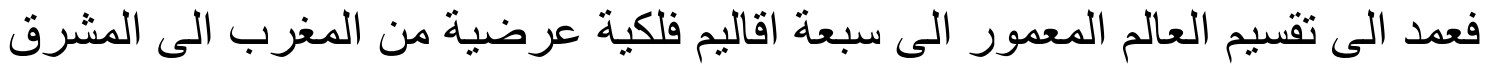

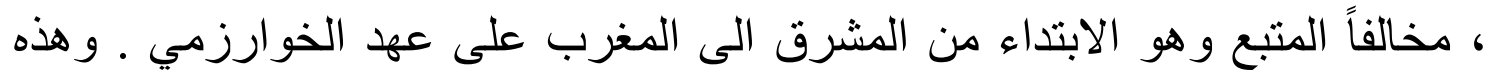

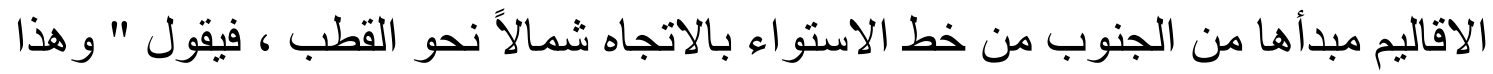

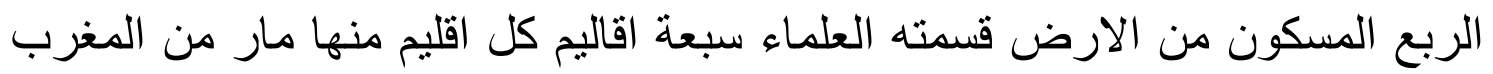

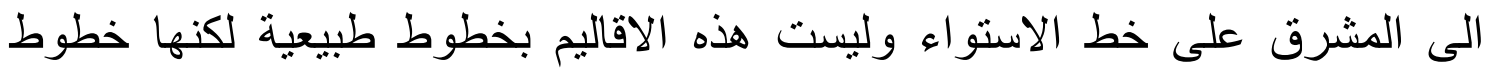

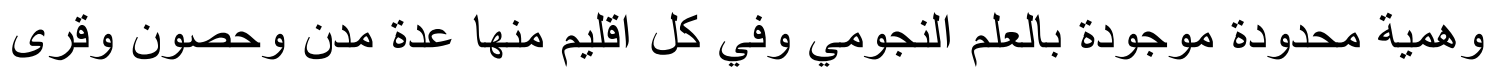

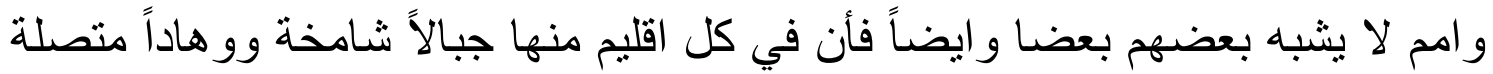

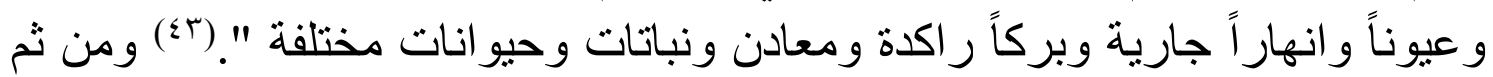

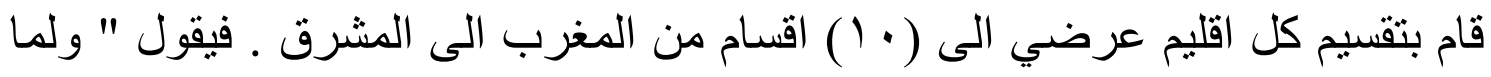

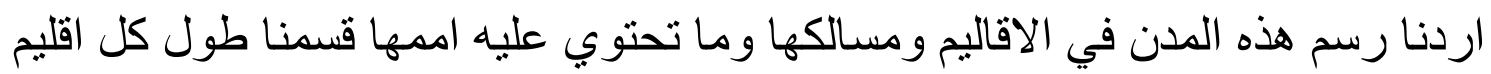

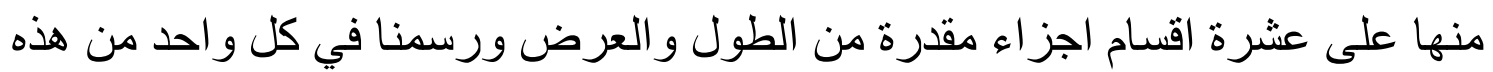

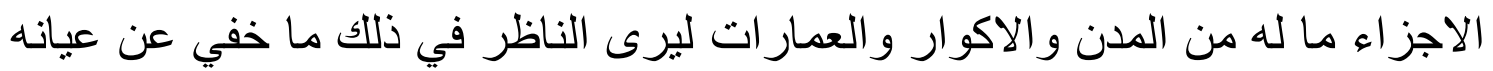

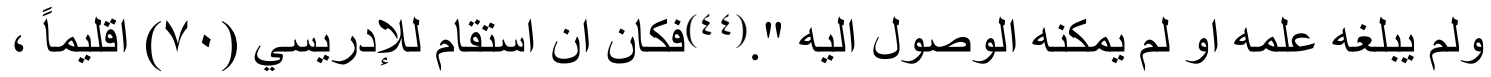

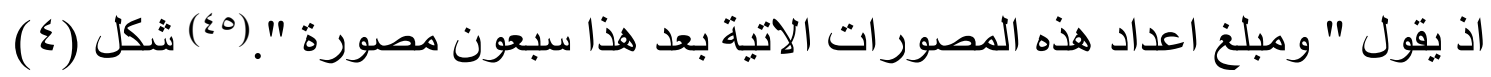

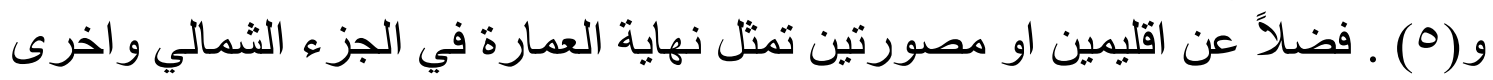

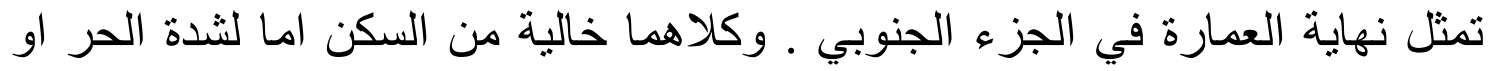

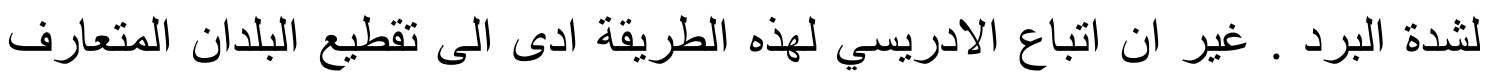

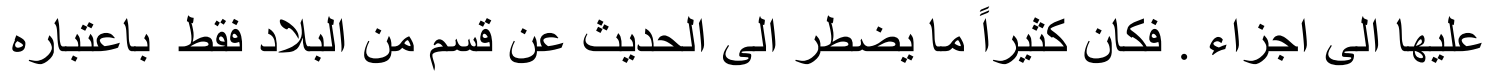

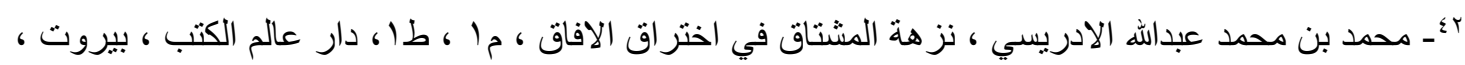


يقع ضمن جزء معين من احد الاقاليم السبعة و الاجزاء العثرة لكل اقليم عرضي ، مؤجلاً الحديث عن بقية البلاد الى ان يأتي دور ها عند شرح الاجزاء الاخرى من

\section{(0) شكل (0)}

خريطة النيل كمثنال على تقسيمات الادريسي

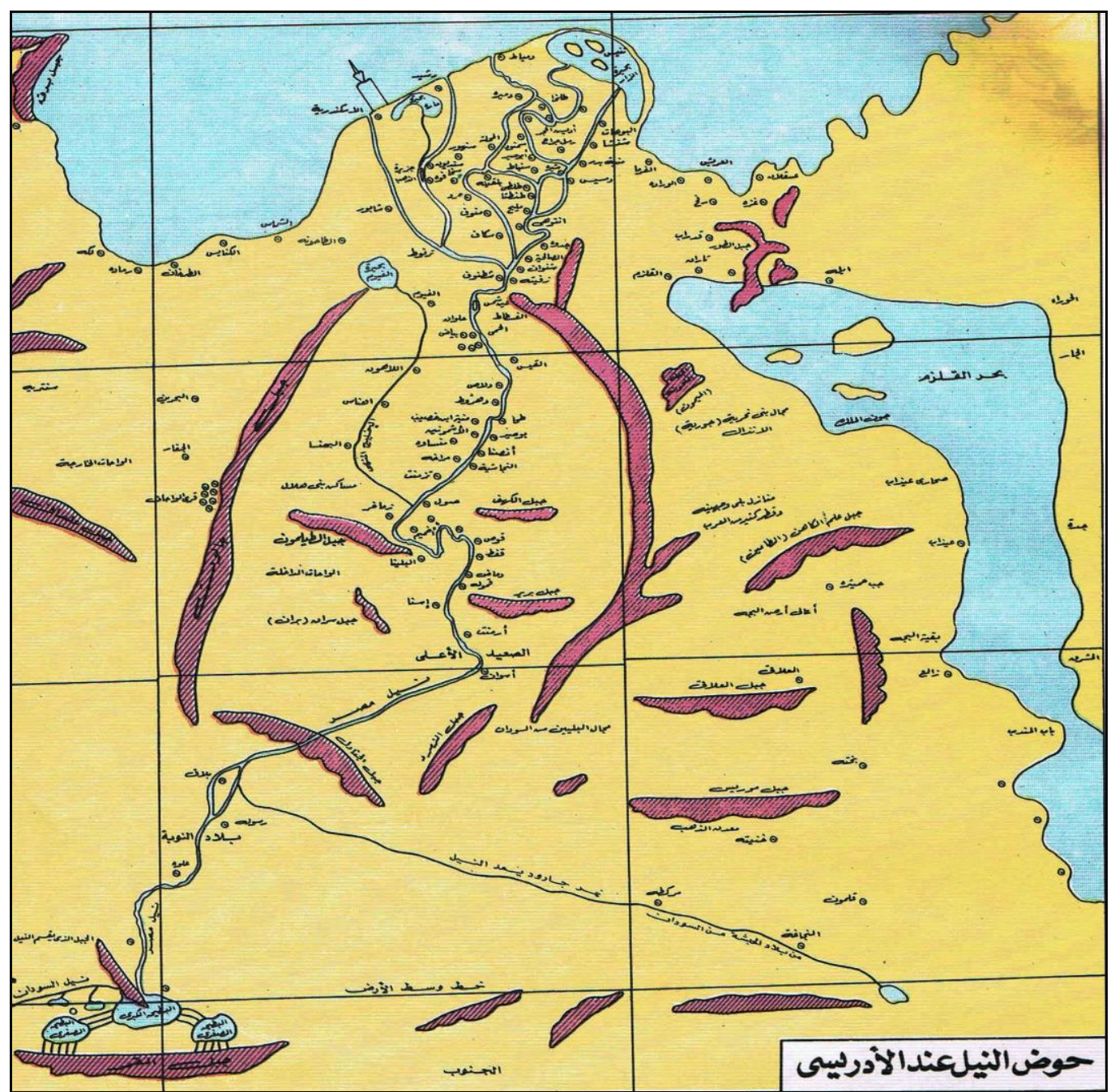

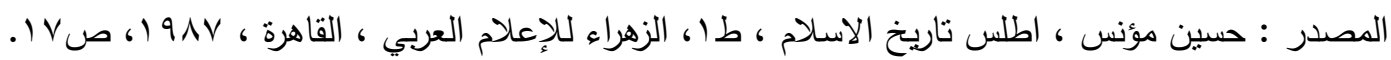




\section{ثامناً: الفكرة الخامسة ( فكرة ابو القداء )}

ما ان وصلت شعلة المعرفة الى ابي الفداء ، و هو الملك المؤيد و العالم الجليل في نهاية

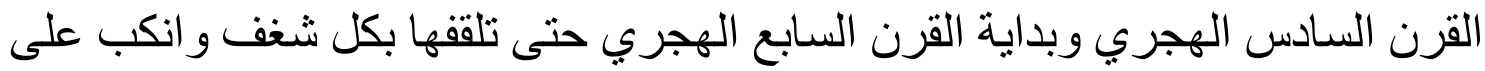

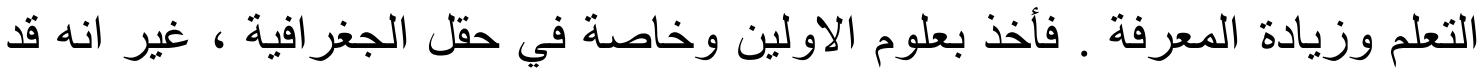

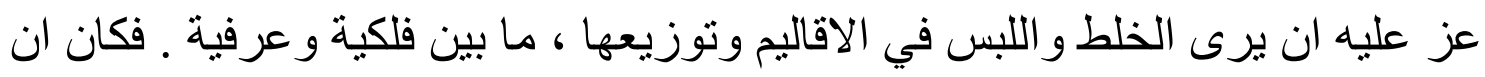

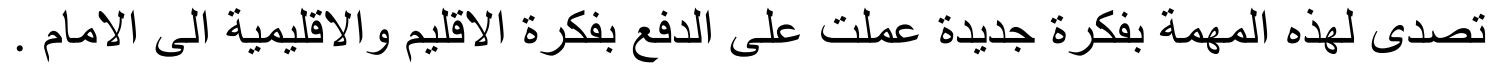

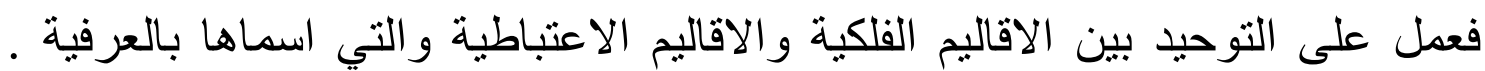

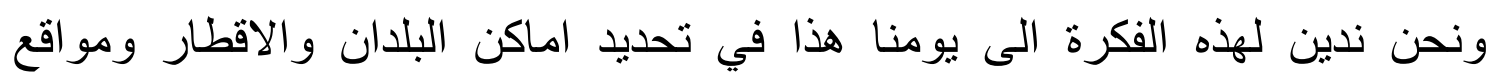

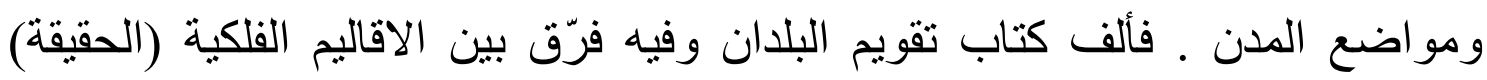

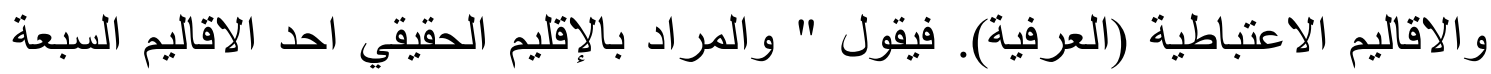

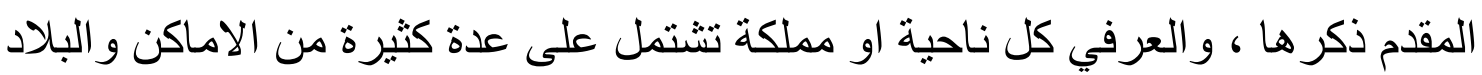

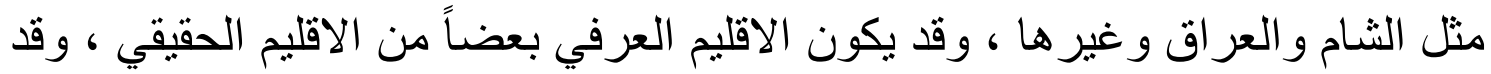

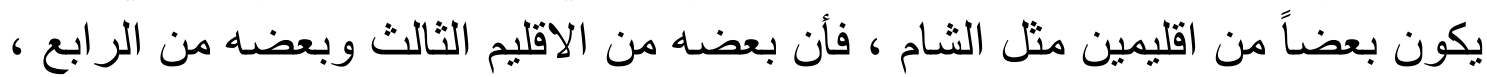

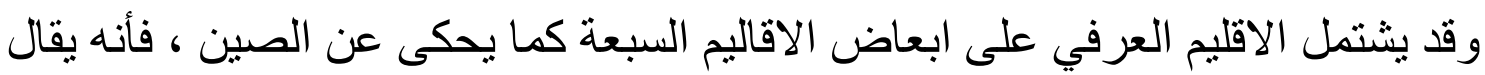

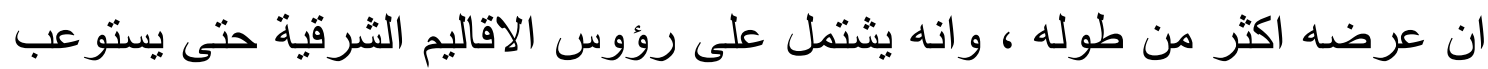

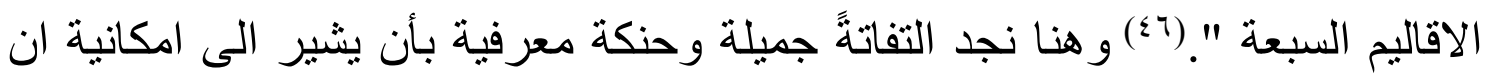

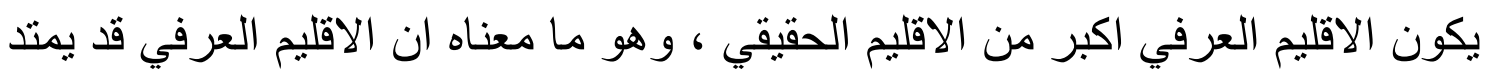

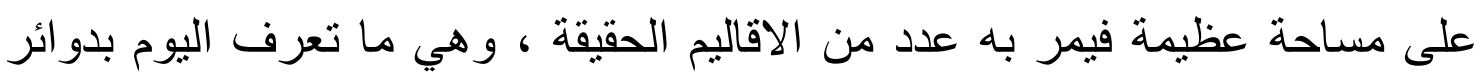

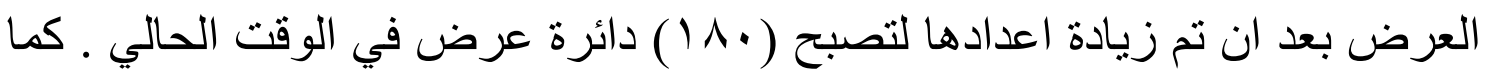

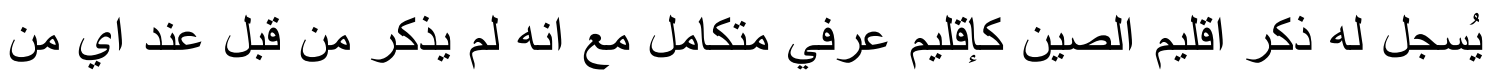

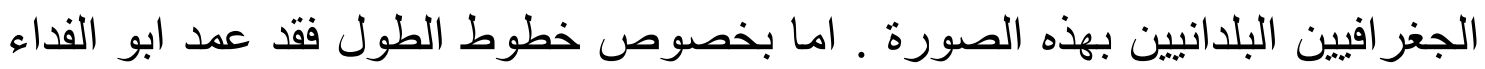

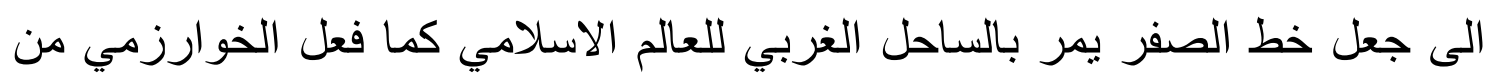
قبله، وبذلك فهو ينقص (• (1) درجات عن خط الصفر الذي كان معتمداً من قبل فيل

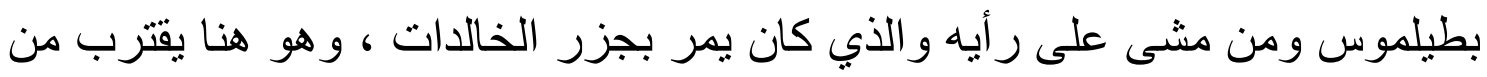

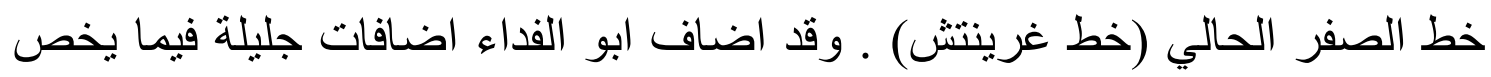


خطوط الطول ، ويتجلى ذلك في امرين الاول : اعتماده مبدأ التقريب ، اي ان المكان

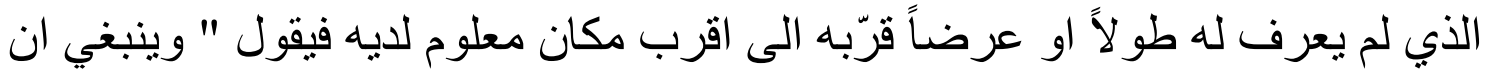

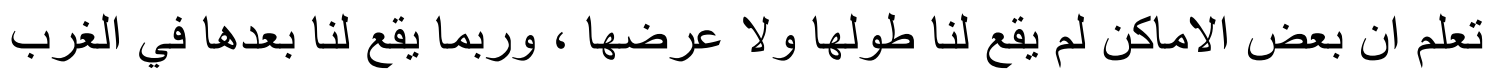

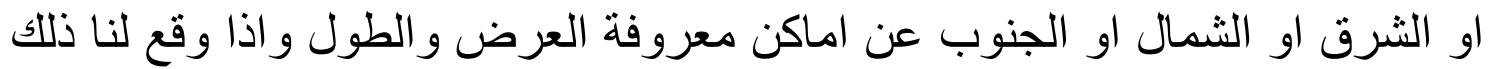

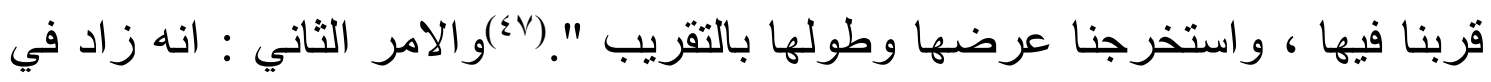

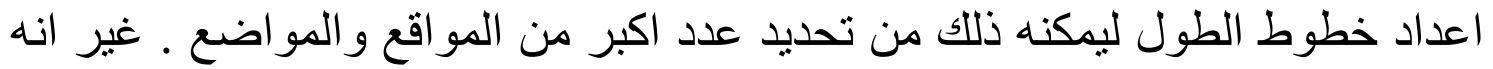

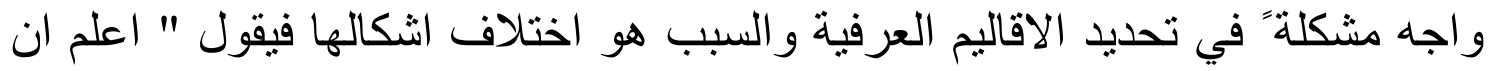

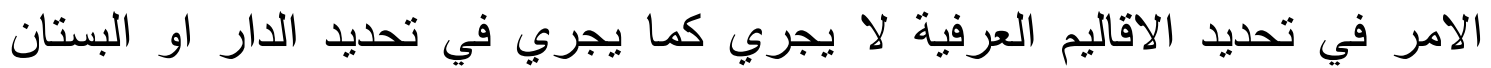

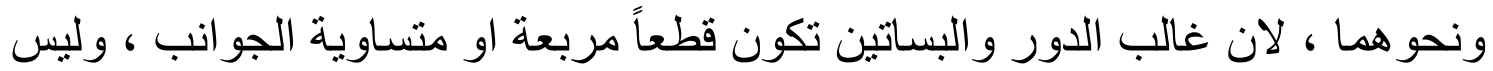

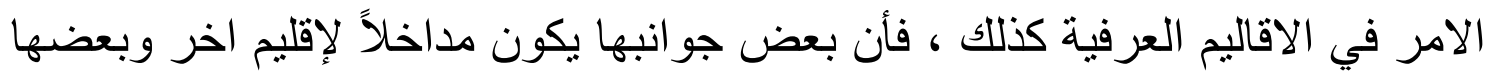
يكون فيه تقويس وبعض جو انبها اعرض من الجانب الاخر ، و الذي يحدد المكان انما

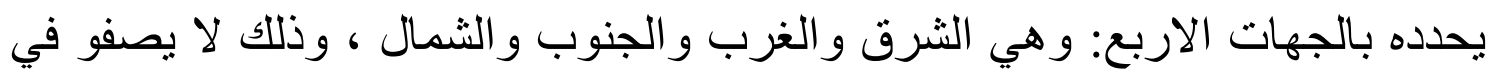
الاقاليم العرفية لما ذكرناه ... وايضاً فأن بعض الأبر الاقاليم يكون على شكل مثلث

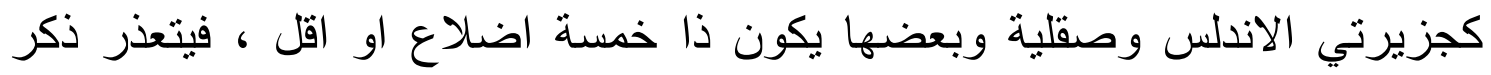

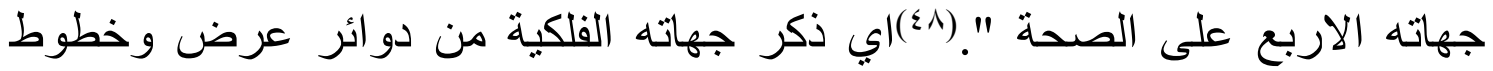

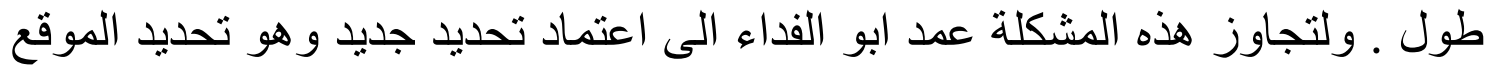

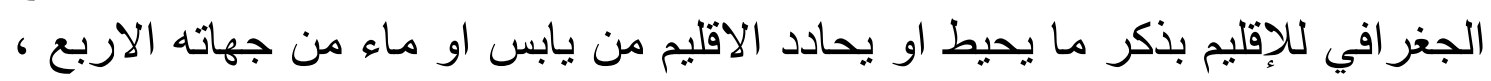

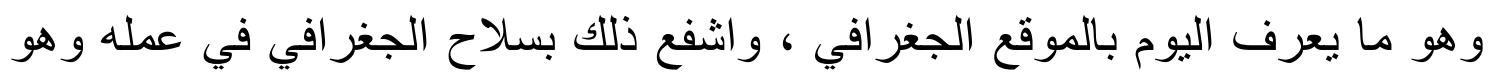

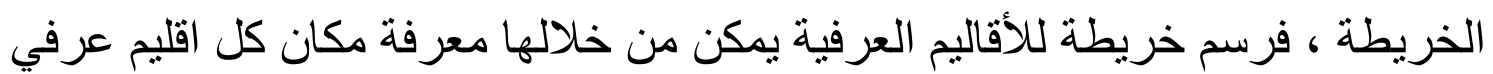

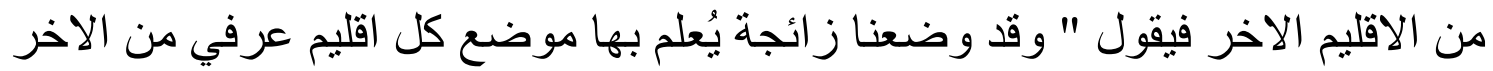

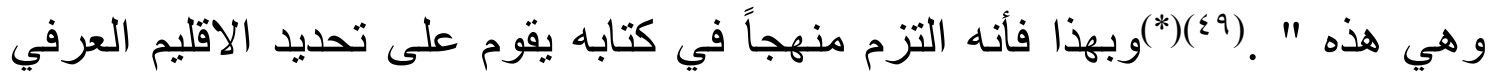

$$
\begin{aligned}
& \text { Vأ_ المصدر نفسه ، ص99. } \\
& \text { ^ــ المصدر نفسه ، ص.^. } \\
& \text { 9ะ ـ المصدر نفسه ، ص اN. }
\end{aligned}
$$

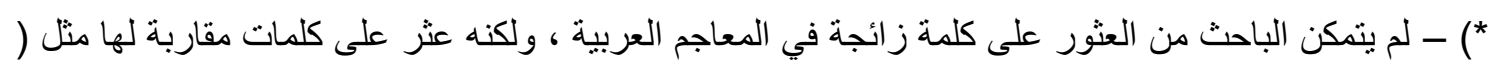

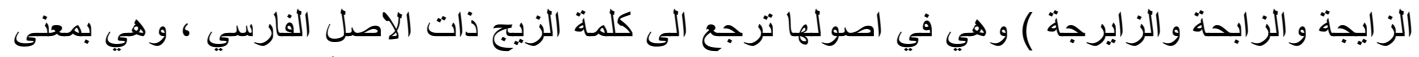

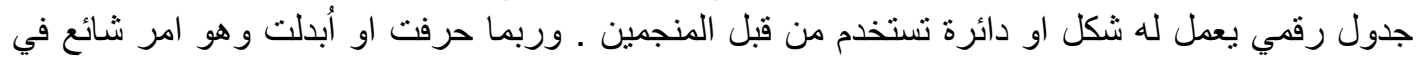




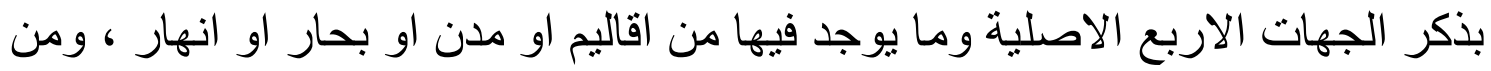

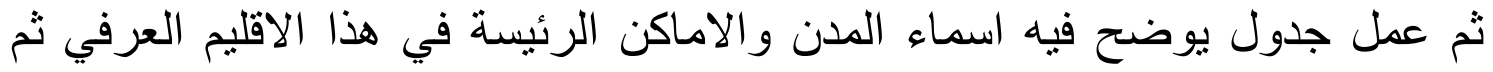

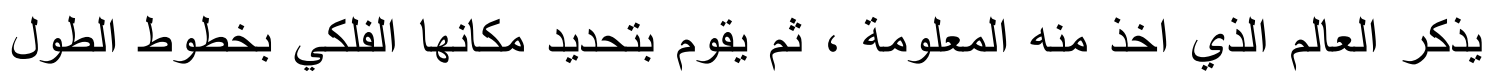

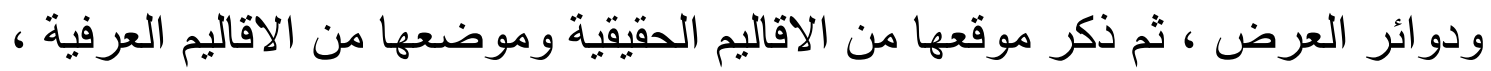

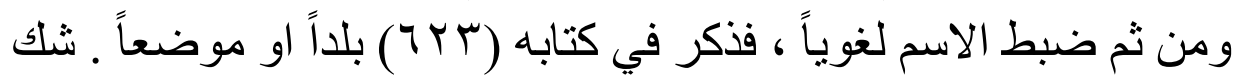
شكل (ך)فكرة ابو الفداء عن الاقاليم

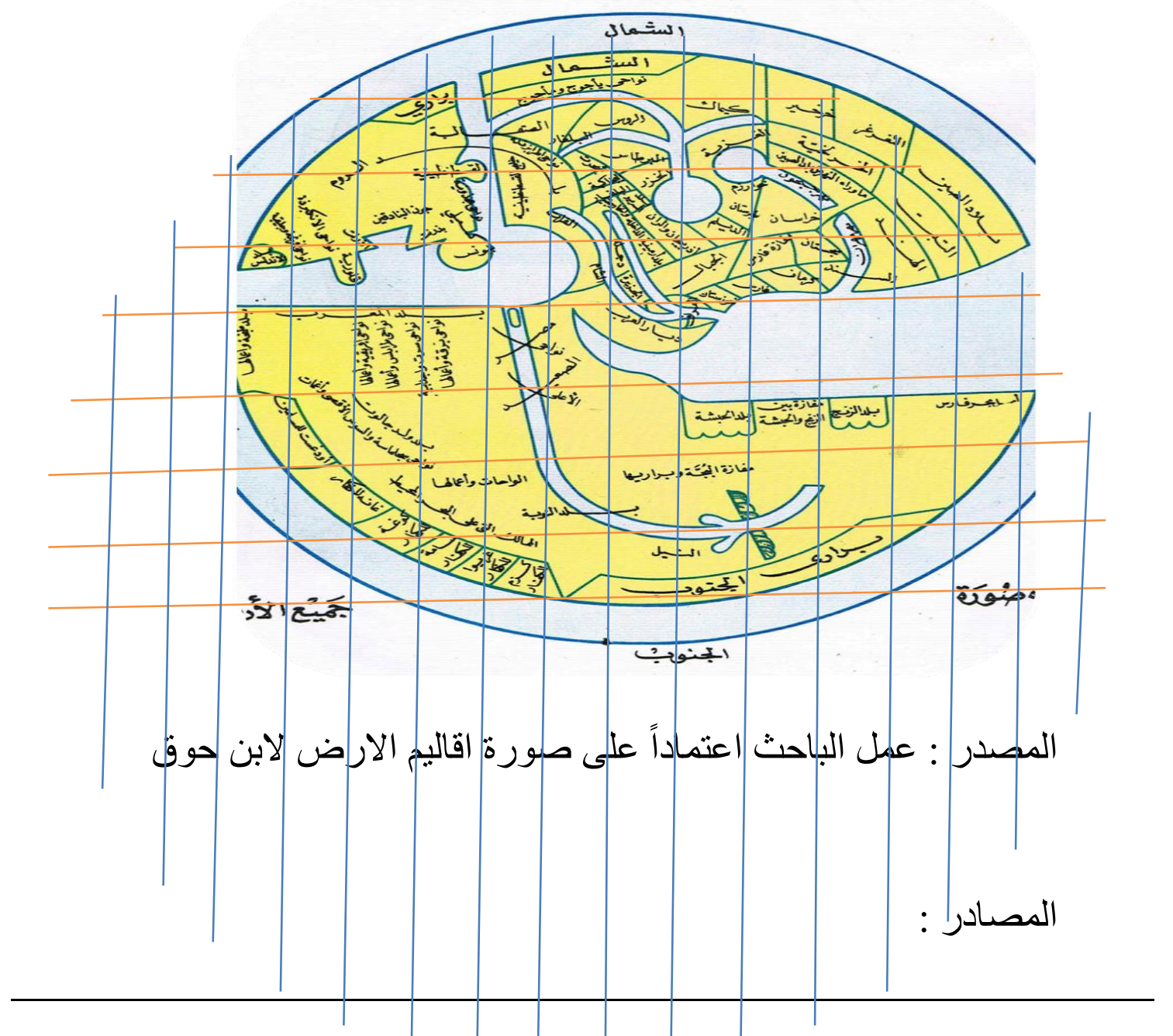

اللغة العربية ، فيقول المستشرق رينهارث دوزي في كتابه تكملة المعاجم العربية " زايرجة وتجمع على وائى

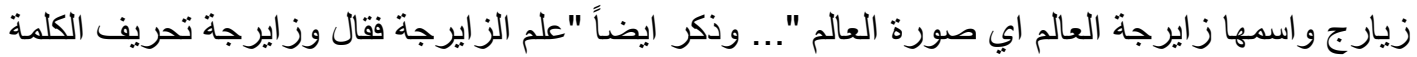

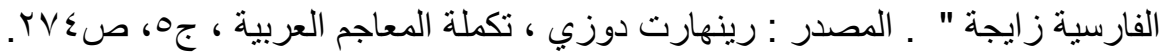


I - ابن حوقل ، ابو القاسم محمد بن علي ، صورة الارض ، طب ، مطبعة بريل ،

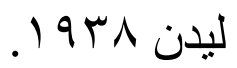

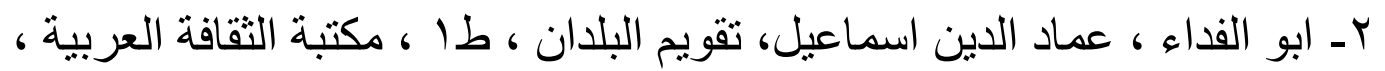

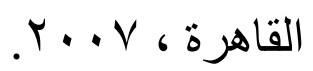

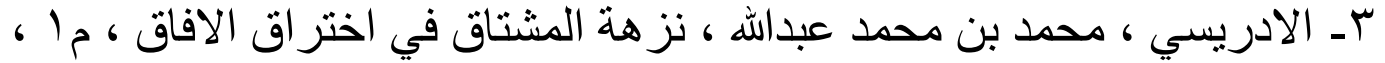

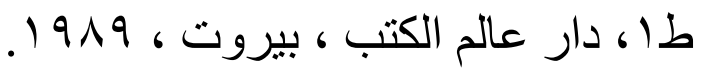

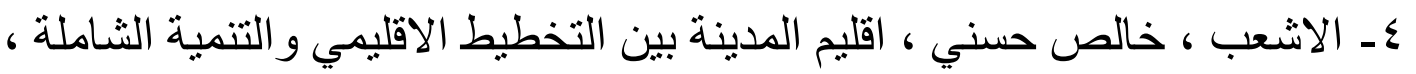

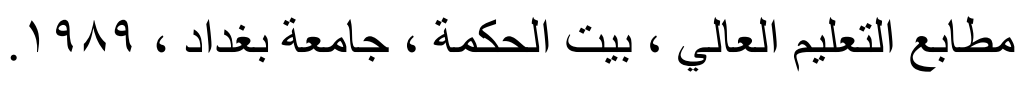

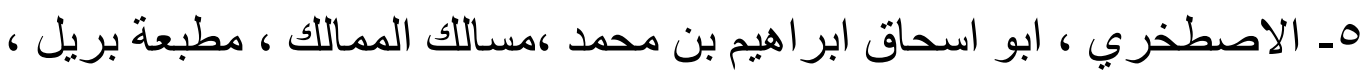

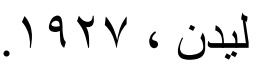

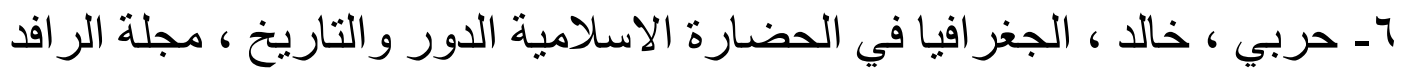

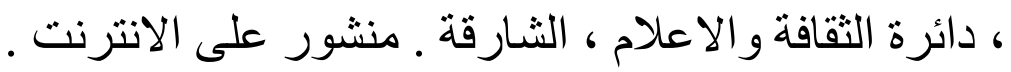

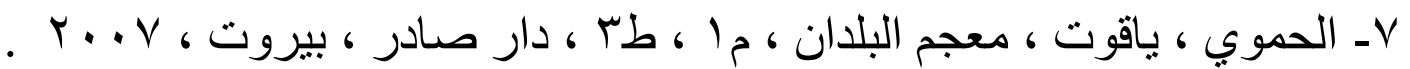

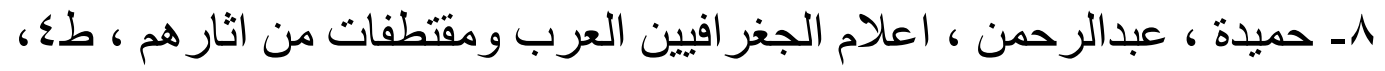

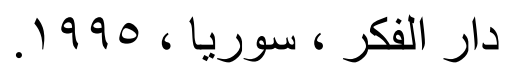

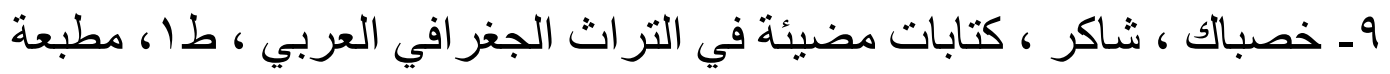

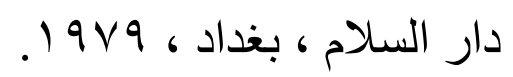

•

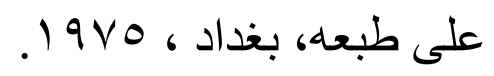

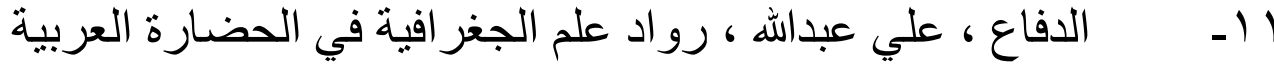

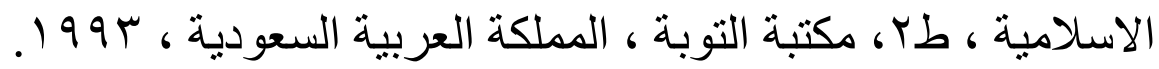

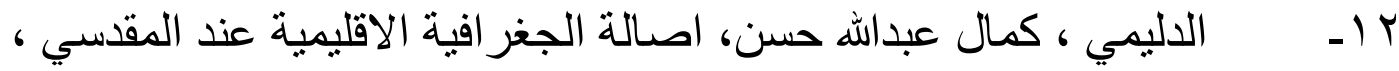

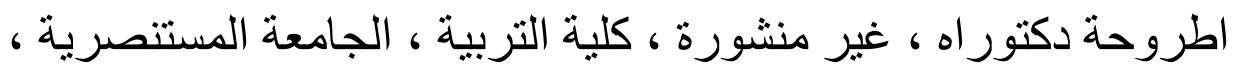

$$
\text { r...T }
$$

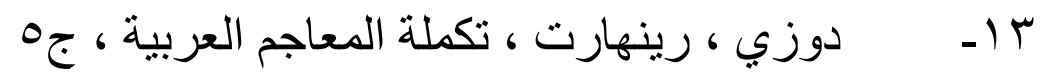

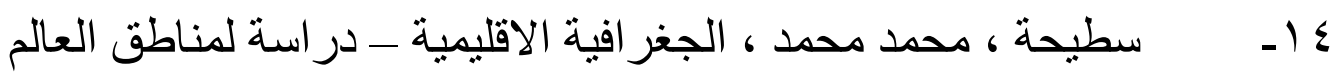

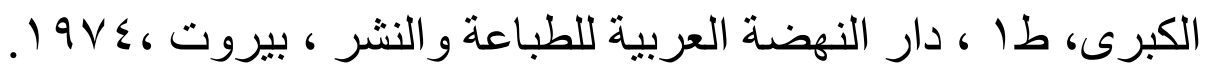




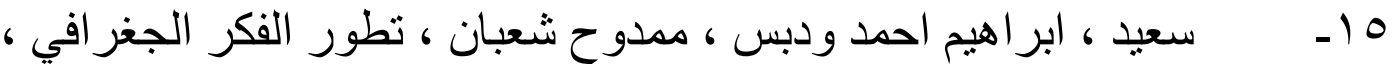

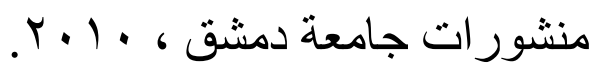

7 ا - سوسة ، احمد ، الثربف الادربسي في الجغرافية العربية ، جل ا، نقابة

المهندسين العراقيين ، مكتبة صبري ، بغداد، ع أو أ.

IV - العبيدي ، نداء نجم الدين احمد ، دور الفكر الجغر افي العربي الاسلامي

في تحديد مفهوم الجغر افية الاقليمية ، اطروحة دكثور اه ، غير منشورة، كلية

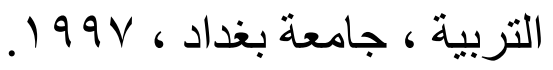

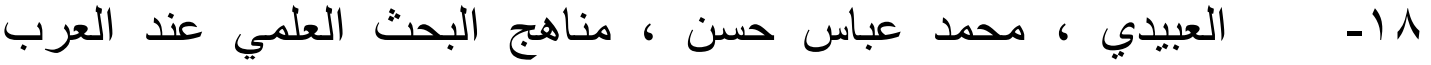

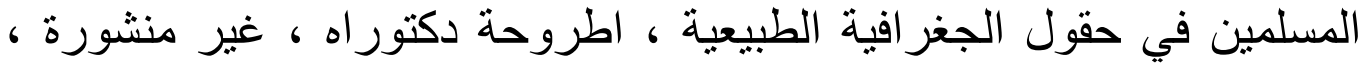

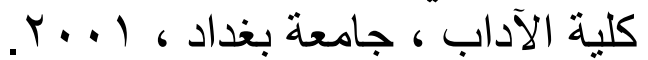
9 ا - عثمان ، صلاح ، طبيعة الحدود بين الجغر افية و الفلسفة ، بحثث منشور

$$
\text { على الانترنت ، } 0 .
$$

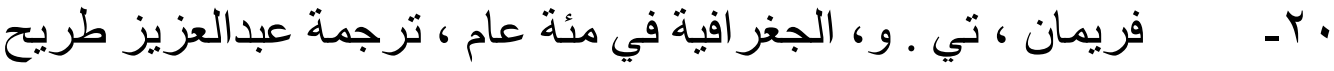
شرف ، دار الثؤون الثقافية ، بغداد ، بدون ت باريخ.

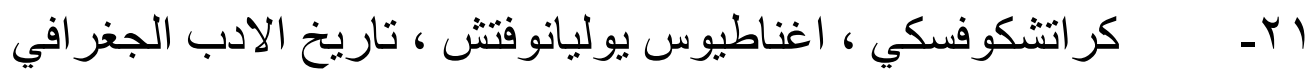
العربي ، ترجمة صلاح الدين عثمان هاشم، طب، دار الغرب الاسلامي، لبنان،

r r- - كلاسون ، جون، مدخل الى التخطيط الاقليمي-المفاهيم النظرية و التطبيق ، ترجمة اميل جميل شمعان ، طب ، ، مطبعة التعليم العالي ، بغداد، $.19 V \lambda$

بr- المقدسي ، محمد بن احمد، احسن التقاسيم في معرفة الاقاليم ، ليدن

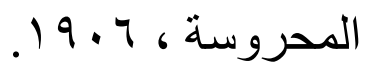

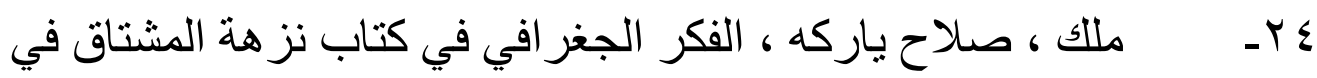
اختر اق الافاق للإدريسي ، رسالة ماجستير ، غير منشورة ، كلية التربية ،

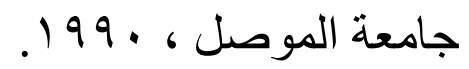

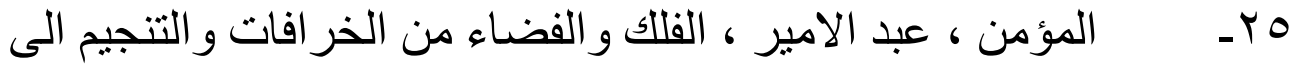

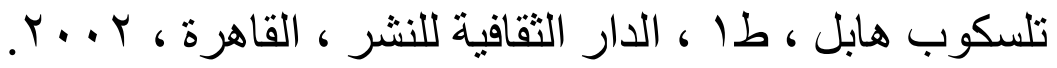


جY - مؤنس ، حسين ، اطلس تأريخ الاسلام ، الزهر هاء للإعلام العربي ،

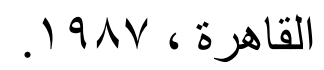

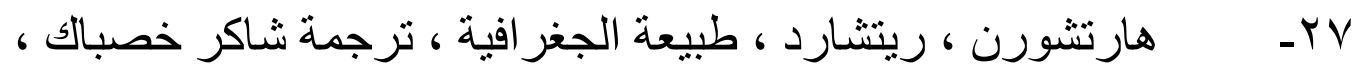

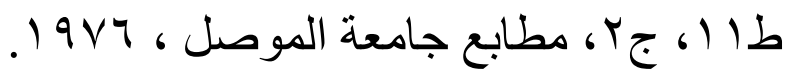

^^ץ ـ الهيتي ، صالح فليح حسن، الخو ارزمي وتطور علم الخر ائط ، مجلة الجمعية

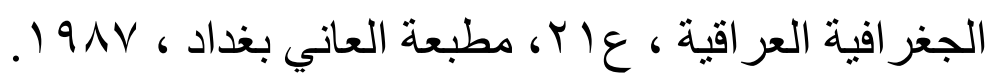

R.E. Dickinson, Regional Concept, The Anglo-America - ${ }^{r^{q}}$

Leaders ,Routledge and KeganPaul, London, , $9 \vee 7, P .101$

David Grigg, Regional, Models and Classes , Models inr.- Geography, Second Published, London, 19^v, P. کт. 